\title{
High-grade prostatic intraepithelial neoplasia
}

\author{
David G Bostwick and Junqi Qian \\ Bostwick Laboratories, Richmond, VA, USA
}

\begin{abstract}
High-grade prostatic intraepithelial neoplasia (PIN) is now accepted as the most likely preinvasive stage of adenocarcinoma, almost two decades after its first formal description. PIN has a high predictive value as a marker for adenocarcinoma, and its identification warrants repeat biopsy for concurrent or subsequent invasive carcinoma. The only method of detection is biopsy; PIN does not significantly elevate serum prostate-specific antigen (PSA) concentration or its derivatives and cannot be detected by current imaging techniques, including ultrasound. Most patients with PIN will develop carcinoma within 10 years. PIN is associated with progressive abnormalities of phenotype and genotype, which are similar to cancer rather than normal prostatic epithelium, indicating impairment of cell differentiation with advancing stages of prostatic carcinogenesis. Androgen deprivation therapy decreases the prevalence and extent of PIN, suggesting that this form of treatment may play a role in chemoprevention.
\end{abstract}

Modern Pathology (2004) 17, 360-379, advance online publication, 23 January 2004; doi:10.1038/modpathol.3800053

Keywords: high-grade prostatic intraepithelial neoplasia; PIN; prostate; adenocarcinoma; diagnosis

High-grade prostatic intraepithelial neoplasia (PIN) is the earliest accepted stage in carcinogenesis, possessing most of the phenotypic, biochemical, and genetic changes of cancer without invasion of the basement membrane of the acini. ${ }^{1-17}$ PIN is the abnormal proliferation within the prostatic ducts, ductules, and large acini of premalignant foci of cellular dysplasia and carcinoma in situ without stromal invasion. ${ }^{18-20}$ The diagnostic term 'prostatic intraepithelial neoplasia' has been endorsed at multiple multidisciplinary and pathology consensus meetings, ${ }^{6,14,21-24}$ and the interobserver agreement between pathologists has been determined to be 'good to excellent' ${ }^{25,26}$ for high-grade PIN. Terms such as dysplasia, malignant transformation, carcinoma in situ, and intraductal carcinoma are discouraged. ${ }^{14,27,28}$

Prostatic intraepithelial neoplasia was originally graded from 1 to 3 , but current recommendations recognize two grades of PIN (low grade and high grade). Grade 1 was defined as low-grade PIN, whereas grades 2 and 3 were currently considered together as high-grade PIN; currently, conventional use of the term 'PIN' without qualification refers to only high-grade PIN. High-grade PIN is a standard diagnosis that must be included as part of the reported pathologic evaluation of prostate biopsies,

Correspondence: Dr DG Bostwick, MD, MBA, FCAP, Bostwick Laboratories, 2807 North Parham Rd, Richmond, VA 23294 USA. E-mail: bostwick@bostwicklaboratories.com

Received 10 December 2003; accepted 10 December 2003; published online 23 January 2004 transurethrally resected prostate chips, and radical prostatectomy specimens. The high level of interobserver variability with low-grade PIN limits its clinical utility, and most pathologists do not report this finding except in research studies, including us.

\section{Epidemiology of PIN}

In the United States, an estimated 1300000 prostate biopsies are performed annually to detect 198500 new cases of prostate cancer. ${ }^{29}$ The incidence of isolated high-grade PIN averages 9\% (range 4-16\%) of prostate biopsies, representing 115000 new cases of high-grade PIN without cancer diagnosed each year (Tables 1, 2). ${ }^{29,30}$

The incidence and extent of PIN appear to increase with patient age (Table 1). ${ }^{31-33}$ An autopsy study of step-sectioned whole mount prostates from older men showed that the prevalence of PIN in prostates with cancer increased with age, predating the onset of carcinoma by more than 5 years. ${ }^{33} \mathrm{~A}$ similar study of young men revealed that PIN is first seen in men in their 20 s and 30 s (9 and $22 \%$ frequency, respectively), and precedes the onset of carcinoma by more than 10 years. ${ }^{33,34}$ Most foci of PIN in young men are low grade, with increasing frequency of high-grade PIN with advancing age. The prevalence of PIN is similar in black and white races. ${ }^{33,34}$ The volume of high-grade PIN also increases with patient age. ${ }^{31}$

Race and geographical location may also influence the incidence of high-grade PIN. ${ }^{5}$ When specific age groups are compared between races, 
there are significant differences in the frequency of high-grade PIN. For example, African-American men have a greater prevalence of high-grade PIN than Caucasians in the 50-60-year-old age group, the decade preceding the manifestation of most clinically detected prostate cancers. ${ }^{21,35-37}$ African-American men also have the highest incidence of prostate cancer (about 50\% more than Caucasians). ${ }^{21,35,36,38,39}$ In contrast, Japanese men living in Osaka, Japan, have a significantly lower incidence of high-grade PIN compared to men residing in the United States, and Asians have the lowest clinically detected rate of prostate cancer. ${ }^{40,41}$ Interestingly, Japanese men diagnosed with high-grade PIN also had an increased likelihood of developing prostate cancer, suggesting that high-grade PIN is a precursor of clinical prostate cancer in Asian men too. ${ }^{42}$ Thus, the differences in the frequency of high-grade PIN in the 50-60-year-old age group across races essentially mirror the rates of clinical prostate cancer observed in the 60-70-year-old age group..$^{35,40}$

The causal association of high-grade PIN with prostatic adenocarcinoma is based on the fact that the prevalence of both high-grade PIN and prostate cancer increases with patient age and that highgrade PIN precedes the onset of prostate cancer by less than one decade (Table 1). ${ }^{33,35,36,43}$ The severity and frequency of high-grade PIN in prostates with cancer is greatly increased (73\% of 731 specimens) when compared to prostates without cancer $(32 \%$ of 876 specimens). ${ }^{31,44-46}$ When high-grade PIN is found on sextant needle biopsy, there is a $50 \%$ risk of finding carcinoma on subsequent biopsies over 3 years ${ }^{23}$ although this risk is lower when more than six cores are obtained. There is also evidence to suggest that high-grade PIN may represent a precursor to a more aggressive form of prostate cancer phenotype than to those who are more likely to remain indolent. ${ }^{10,42,47}$

\section{Incidence of PIN}

The incidence of PIN varies according to the population of men under study (Table 2). ${ }^{48-54}$ The lowest likelihood is in men participating in PSA

Table 1 Estimated frequency of men harboring high-grade PIN in the United States

\begin{tabular}{lcrr}
\hline Age (years) & High-grade \% PIN & US population ${ }^{a}$ (thousands) & Number of PIN \\
\hline $40-49$ & 15.2 & 20550 & 3123600 \\
$50-59$ & 24.0 & 14187 & 3404880 \\
$60-69$ & 47.3 & 9312 & 4404576 \\
$70-79$ & 58.4 & 6926 & 4044784 \\
$80-89$ & 70.0 & 2664 & 1864800 \\
& Total & 53639000 & 16842640 \\
\hline
\end{tabular}

${ }^{\mathrm{a}} 1990$ US census.

Table 2 Incidence of isolated high-grade PIN in prostatic needle biopsies

\begin{tabular}{|c|c|c|c|}
\hline Reference & Patient population & No. of men & $\begin{array}{l}\text { Incidence of } \\
\quad P I N(\%)\end{array}$ \\
\hline \multicolumn{4}{|l|}{ Screening programs } \\
\hline Mettlin et al $(1991)^{178}$ & $\begin{array}{l}\text { American Cancer Society National Prostate Cancer Detection } \\
\text { Project }\end{array}$ & 330 & 5.2 \\
\hline Richie et al (1994) ${ }^{48}$ & Screening population & 163 & 8.6 \\
\hline Feneley et al (1997) ${ }^{179}$ & Screening population in Gwent, England, 1991-1993 & 212 & 20 \\
\hline Hoedemaeker et al $(1999)^{50}$ & PSA screening study in Rotterdam (Netherlands) & 1824 & 0.7 \\
\hline \multicolumn{4}{|l|}{ Urology practice } \\
\hline Lee et al $(1989)^{32}$ & $\begin{array}{l}\text { Consecutive biopsies of hypoechoic lesions at St. Joseph } \\
\text { Mercy Hospital }\end{array}$ & 256 & 11 \\
\hline Bostwick et al (1995) $)^{180}$ & Consecutive biopsies at Mayo Clinic & 200 & 16.5 \\
\hline Bostwick et al (1995) ${ }^{180}$ & Consecutive biopsies at Glendale Hospital (CA) & 200 & 10.5 \\
\hline Langer et al $(1996)^{51}$ & Consecutive biopsies at University of Pennsylvania Med. Ctr. & 1275 & 4.4 \\
\hline Wills et al $(1997)^{52}$ & Consecutive biopsies at Johns Hopkins Hospital & 439 & 5.5 \\
\hline Skjorten et al $(1997)^{53}$ & $\begin{array}{l}\text { Consecutive biopsies from } 1974-1975 \text { at Ullevaal and } \\
\text { Lovisenberg Hospitals, Oslo, Norway }\end{array}$ & 79 & 7.6 \\
\hline Perachino et al $(1997)^{54}$ & Consecutive biopsies & 148 & 14.1 \\
\hline Feneley et al $(1997)^{49}$ & $\begin{array}{l}\text { Consecutive biopsies at University College London Hospitals } \\
\text { 1988-1994 }\end{array}$ & 1205 & 11 \\
\hline Feneley et al (1997) ${ }^{49}$ & $\begin{array}{l}\text { Consecutive biopsies of symptomatic men at St. } \\
\text { Bartholomew's Hospital, London, 1993-1994 }\end{array}$ & 118 & 25 \\
\hline
\end{tabular}


screening and early detection studies, with an incidence of PIN in biopsies ranging from 0.7 to $20 \%{ }^{48-54}$

Men seen by urologists in practice have PIN in $4.4-25 \%$ of contemporary needle biopsies. Those undergoing transurethral resection have the highest likelihood of PIN, varying from 2.8 to $33 \%$ (Table 3). ${ }^{53,55,56}$ In such cases, all tissue should be examined, but serial sections of suspicious foci are usually not necessary. Unfortunately, needle biopsy specimens fail to show the suspicious focus on deeper levels in about half of cases, precluding assessment by immunohistochemistry and compounding the diagnostic dilemma.

\section{Diagnostic criteria of PIN}

There are four main patterns of high-grade PIN: tufting, micropapillary, cribiform, and flat (Figures $1-4) .{ }^{57}$ The tufting pattern is the most common, present in $97 \%$ of cases, although most cases have multiple patterns. There are no known clinically important differences between the architectural patterns of high-grade PIN, and their recognition appears to be only of diagnostic utility. Nonetheless, one report suggested that the cribriform pattern may indicate higher risk of coexistent cancer, but this has been refuted. Other unusual patterns of PIN include the signet ring cell pattern,

Table 3 Incidence of isolated high-grade pin in prostatic transurethral resections

\begin{tabular}{|c|c|c|c|c|}
\hline Reference & Specimen & Patient population & $\begin{array}{l}\text { Number of } \\
\text { men }\end{array}$ & $\begin{array}{l}\text { Incidence of } \\
\operatorname{PIN}(\%)\end{array}$ \\
\hline Gaudin et al (1997) $)^{55}$ & TURP & Consecutive TURPs without cancer at Johns Hopkins Hospital & 158 & 3.2 \\
\hline $\begin{array}{l}\text { Pacelli and } \\
\text { Bostwick (1997) }\end{array}$ & TURP & Consecutive TURPs without cancer at Mayo Clinic & 570 & 2.8 \\
\hline $\begin{array}{l}\text { Skjorten et al } \\
(1997)^{53}\end{array}$ & TURP & $\begin{array}{l}\text { Consecutive TURPs from } 1974-1975 \text { at Ullevaal and } \\
\text { Lovisenberg Hospitals, Oslo, Norway }\end{array}$ & 731 & 33 \\
\hline
\end{tabular}
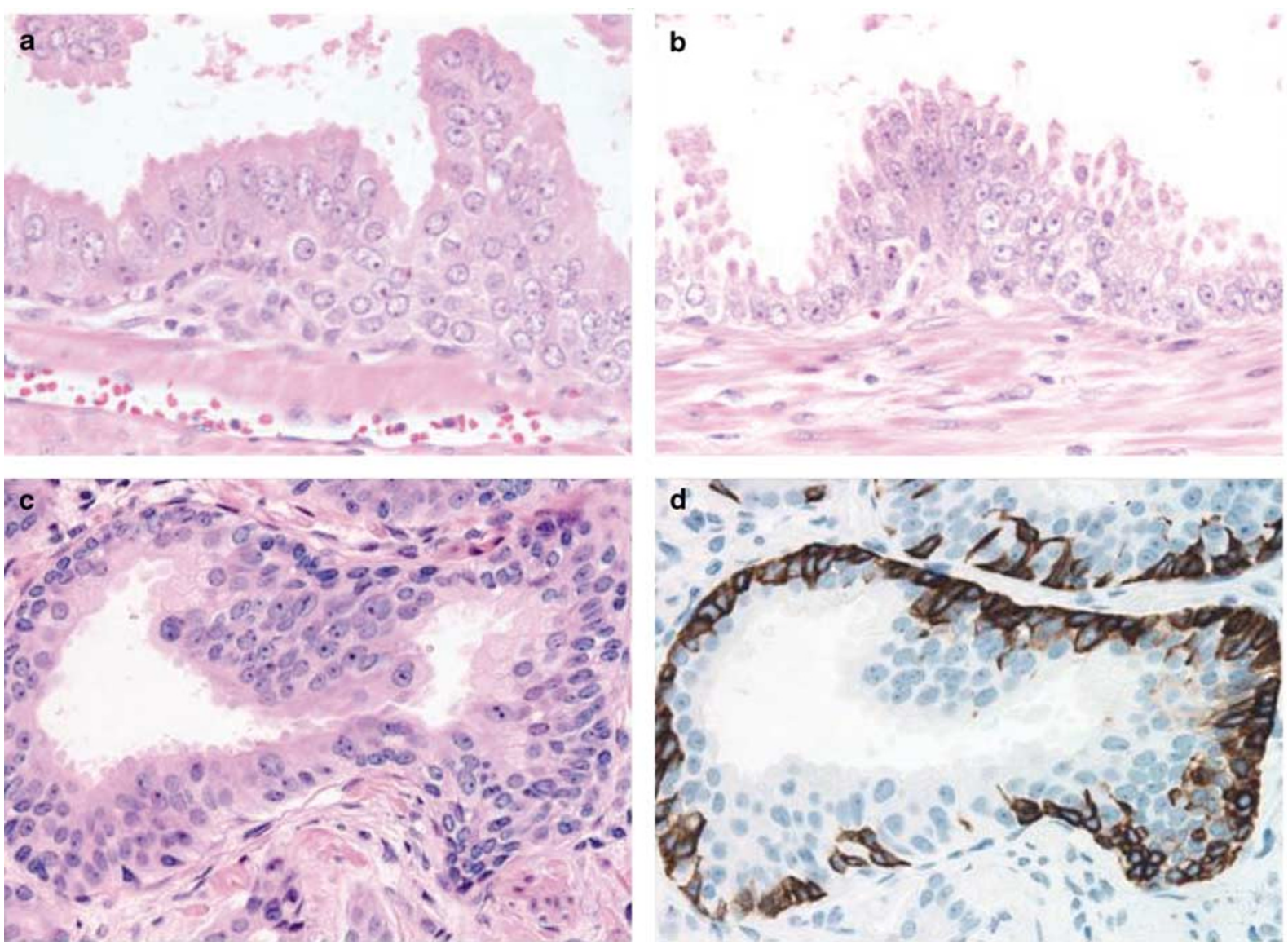

Figure 1 High-grade PIN, tufting pattern. (a) (b) and (c) Epithelial cell crowding and stratification with prominent nuclei and nucleoli; (d) immunostain for basal cell-specific high molecular weight keratin (34 $\beta$ E12) reveals basal cell layer disruption in high-grade PIN. 

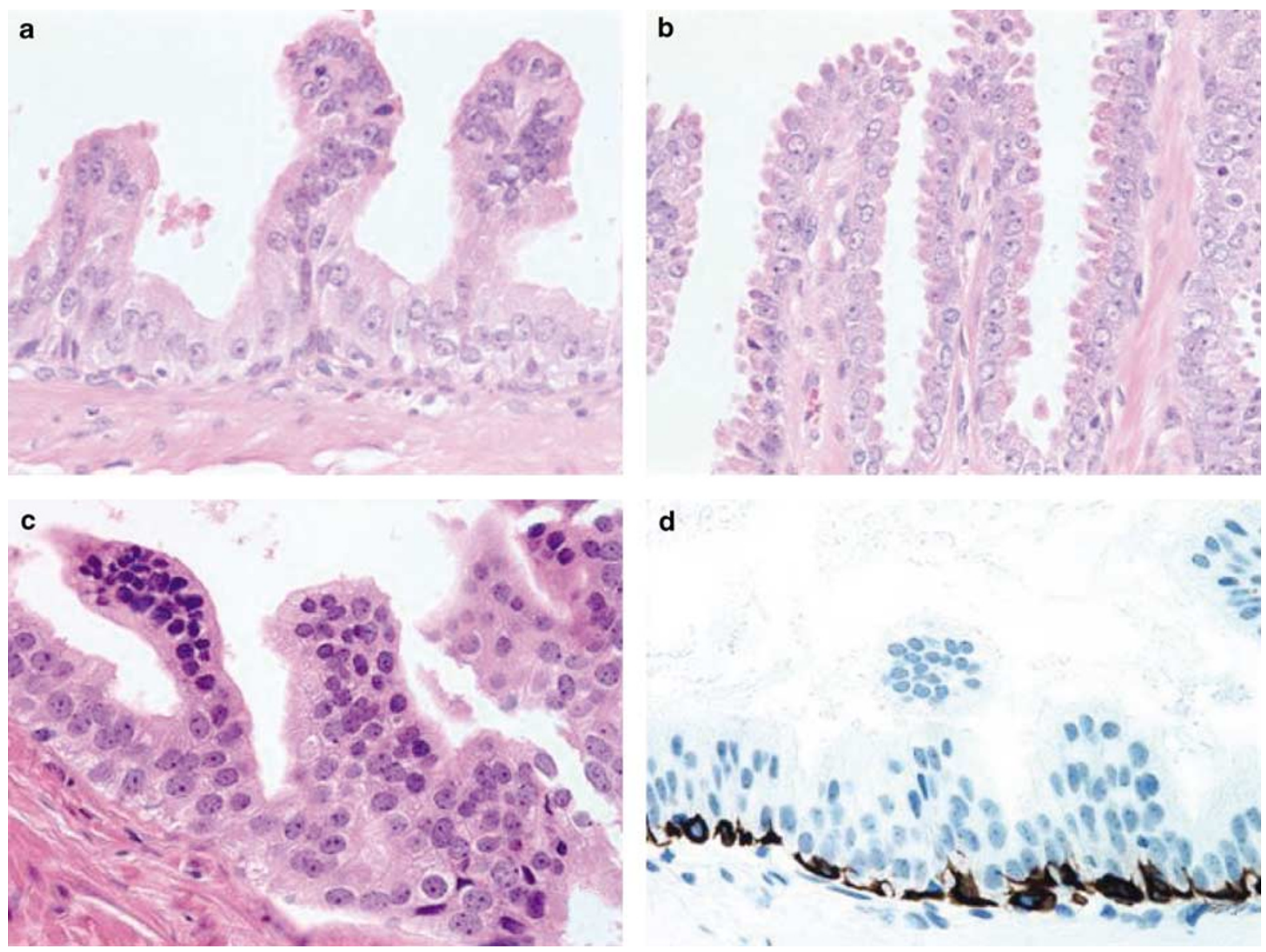

Figure 2 High-grade PIN, micropapillary pattern.

small-cell neuroendocrine pattern, and foamy gland pattern (Figures 5-8). ${ }^{58}$

There is inversion of the normal orientation of epithelial proliferation with PIN; most proliferation normally occurs in the basal cell compartment, whereas in PIN, the greatest proliferation occurs on the luminal surface, similar to preinvasive lesions in the colon (tubular adenoma) and other sites.

PIN spreads through prostatic ducts in multiple different patterns, similar to prostatic carcinoma. In the first pattern, neoplastic cells replace the normal luminal secretory epithelium, with preservation of the basal cell layer and basement membrane. This pattern often has a cribriform or near-solid appearance. Foci of high-grade PIN are usually indistinguishable from intraductal/intra-acinar spread of carcinoma by routine light microscopy. ${ }^{59}$ In the second pattern, there is direct invasion through the ductal or acinar wall, with disruption of the basement membrane and basal cell layer. In the third pattern, neoplastic cells invaginate between the basal cell layer and columnar secretory cell layer ('pagetoid spread'), a very rare finding.

Early stromal invasion, the earliest evidence of carcinoma, occurs at sites of acinar outpouching and basal cell disruption in acini with high-grade PIN. Such microinvasion is present in about $2 \%$ of high-power microscopic fields of PIN, and is seen with equal frequency with all architectural patterns. ${ }^{57}$

The mean volume of PIN in prostates with cancer is $1.2-1.32 \mathrm{~cm}^{3}$, and the volume increases with increasing pathologic stage, Gleason grade, positive surgical margins, and perineural invasion. ${ }^{31,60}$ These findings underscore the close spatial and biologic relationship of PIN and cancer, and may result from an increase in PIN with increasing cancer volume. PIN and cancer are usually multicentric. ${ }^{31,57,11} \mathrm{PIN}$ is multicentric in $72 \%$ of radical prostatectomies with cancer, including $63 \%$ of those involving the nontransition zone and $7 \%$ of those involving the transition zone; $2 \%$ of cases have concomitant single foci in all zones. ${ }^{31}$ The peripheral zone of the prostate, the area in which the majority of prostatic carcinomas occur $(70 \%)$, is also the most common location for PIN. ${ }^{31-57}$ Cancer and PIN are frequently multicentric in the peripheral zone, indicating a 'field' effect similar to the multicentricity of urothelial carcinoma of the bladder.

High-grade PIN and prostate cancer are morphometrically and phenotypically similar. High-grade PIN occurs primarily in the peripheral zone and is seen in areas that are in continuity with prostate cancer. $^{6,31,37,46,61,62}$ High-grade PIN and prostate 

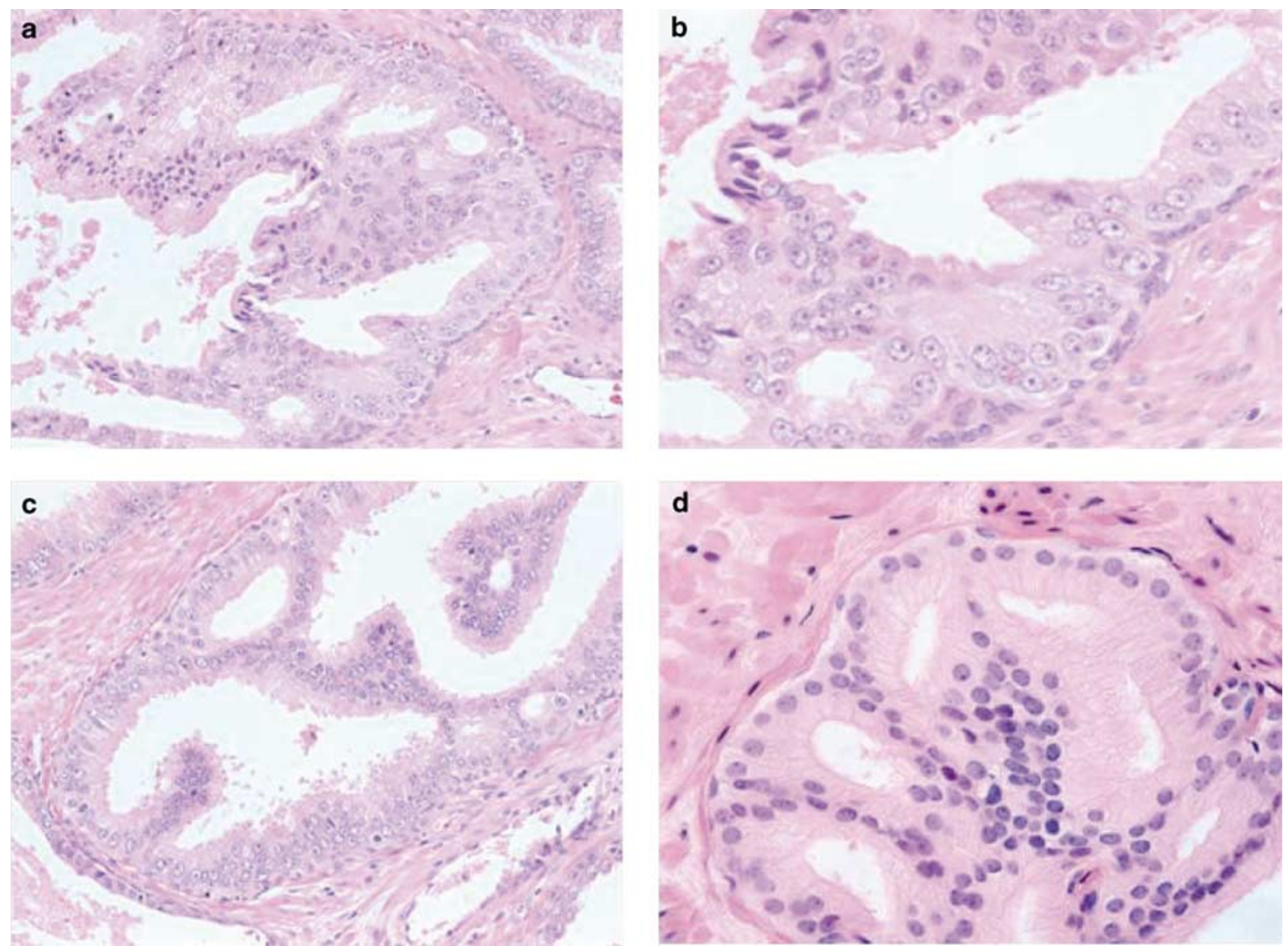

Figure 3 High-grade PIN, cribriform pattern.

cancer are multifocal and heterogeneous. ${ }^{31,63,64}$ Increasing rates of aneuploidy and angiogenesis as the grade of PIN progresses are further evidence that high-grade PIN is a precancer., ${ }^{1,62,65-68}$ Prostate cancer and high-grade PIN also have similar proliferative and apoptotic indices. ${ }^{1,3,40,69-74}$

It is often difficult with small foci in needle biopsies to separate cancer from suspicious foci (atypical small acinar proliferation suspicious for but not diagnostic of malignancy) when there is coexistent high-grade PIN; the difficulty is based on the inability to separate tangential cutting of the larger pre-existing acini of PIN (that may appear as small separate adjacent acini) from the smaller discrete acini of cancer.

Recent renewed efforts to introduce the term 'intraductal carcinoma' rely on the abandoned concept that dysplasia (defined here as malignancy arising at that specific site within the epithelium) can be separated reliably from intraductal/intracinar spread of cancer (defined here as extension of malignant cells through the pre-existing lumens of the prostate); however, this concept was rejected by consensus on multiple occasions owing to lack of reproducible criteria for making this distinction, and the noncommittal term intraepithelial neoplasia was internationally adopted and repeatedly recon- firmed as it begs the question of site of origin of the process. Those who persist with the belief that 'intraductal carcinoma' can be diagnosed rely on proximity of the epithelial abnormality to invasive cancer, but this criterion is arbitrary and not based on valid objective confirmatory data. More importantly, there is no clinical utility at present that requires separation of dysplasia and intraductal/ intra-acinar spread of cancer-the clinical response is the same. It is conceivable that future studies may allow diagnostic separation of dysplasia and intraductal/ intra-acinar spread of cancer; if so, then these steps in the biologic progression of prostate cancer may be shown to have differential predictive value for prostate cancer. We agree that identification of subsets of high-grade PIN that indicate greater risk of cancer is a clinically important area of investigation.

\section{Immunohistochemistry of PIN}

Select antibodies such as anti-keratin $34 \beta$-E12 (high molecular weight keratin) or p63 may be used to stain tissue sections for the presence of basal cells, recognizing that PIN retains an intact or fragmented basal cell layer whereas cancer does not. 

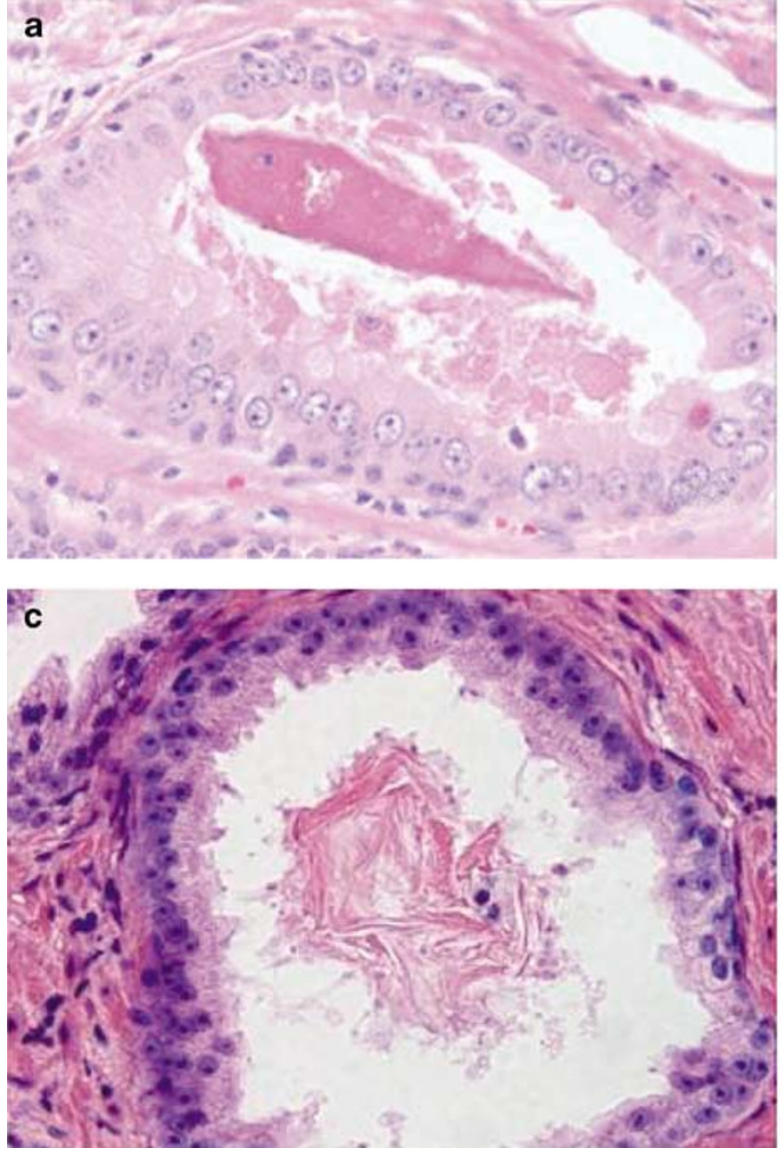
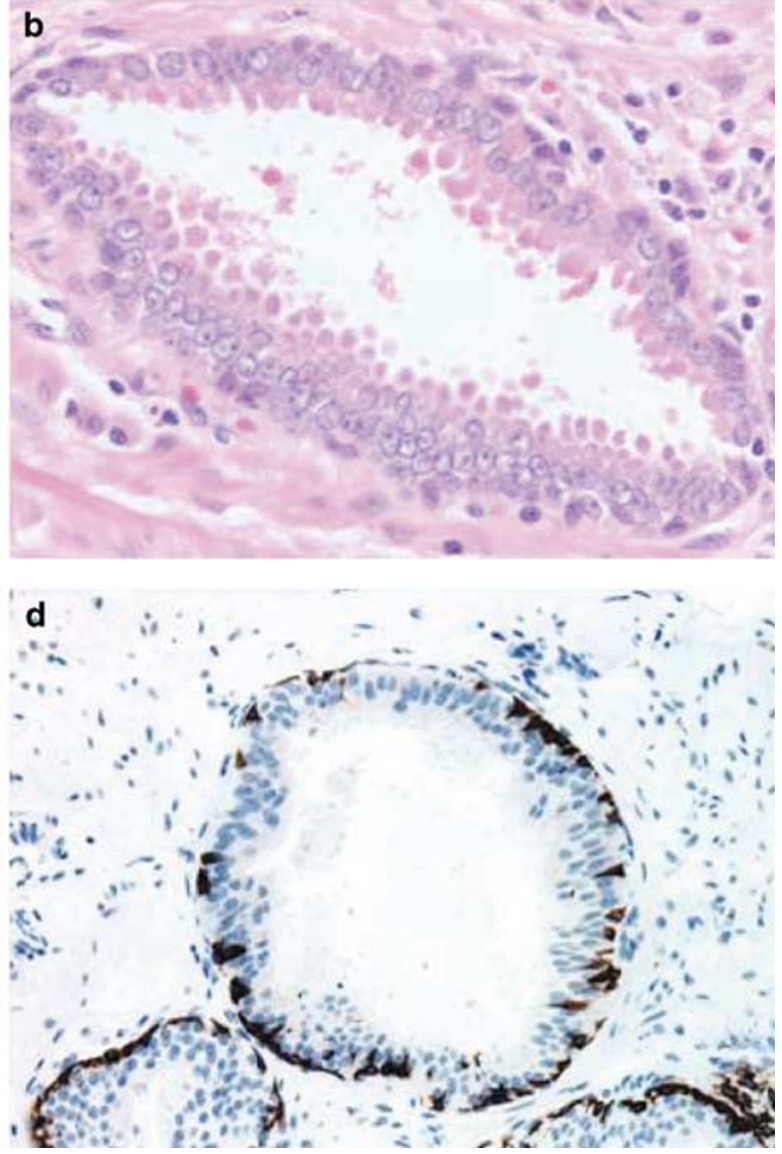

Figure 4 High-grade PIN, flat pattern.

Monoclonal basal cell-specific antikeratin 34 $\beta$-E12 stains virtually all of the normal basal cells of the prostate, with continuous intact circumferential staining in many instances. There is no staining in the secretory and stromal cells. This marker is the most commonly used immunostain for prostatic basal cells, ${ }^{75-77}$ and methods of use with paraffinembedded sections have recently been optimized. ${ }^{78}$ Keratin $34 \beta$-E12 is formalin sensitive and requires pretreatment by enzymes or heat if formalin-based fixatives are used. After pepsin predigestion or microwaving, there is progressive loss of immunoreactivity from one week or longer of formalin fixation. Heat-induced epitope retrieval with a hot plate yielded consistent results with no decrease in immunoreactivity with as long as 1 month of formalin fixation. ${ }^{78}$ The staining intensity was consistently stronger at all periods of formalin fixation when the hot plate method was used, compared with pepsin predigestion or microwaving. Weak immunoreactivity was rarely observed in cancer cells after hot plate treatment, but not with pepsin predigestion or microwave antigen retrieval. Our laboratory reported that steam-EDTA in combination with protease significantly enhanced basal cell immunoreactivity compared with protease treatment alone in noncancerous prostatic epithelium (Figures 1d, 2d, $4 \mathrm{~d}$ and $5 \mathrm{~d}$ ). ${ }^{79}$ Nonreactive benign acini were always the most peripheral acini in a lobule, a small cluster of outpouched acini furthest from a large duct, or the terminal end of a large duct. ${ }^{80}$ More proximal acini had a discontinuous pattern of immunoreactivity. Electron microscopy showed occasional acini with luminal cells abutting the basement membrane, without the interposition of basal cell cytoplasm, and other acini with extremely attenuated basal cell cytoplasmic processes containing sparse bundles of intermediate filaments.

Increasing grades of PIN are associated with progressive disruption of the basal cell layer, according to studies utilizing antikeratin $34 \beta$-E 12 . Basal cell layer disruption is present in $56 \%$ of cases of high-grade PIN, and is more frequent in acini adjacent to invasive carcinoma than in distant acini (Figures 1d, 2d, 4d and 5d). The amount of disruption increases with increasing grades of PIN. Early invasive carcinoma occurs at sites of glandular outpouching and basal cell discontinuity in association with PIN. ${ }^{20}$ The cribriform pattern of PIN may be mistaken for cribriform adenocarcinoma, and the use of antikeratin staining is invaluable in making this distinction. ${ }^{81}$ 

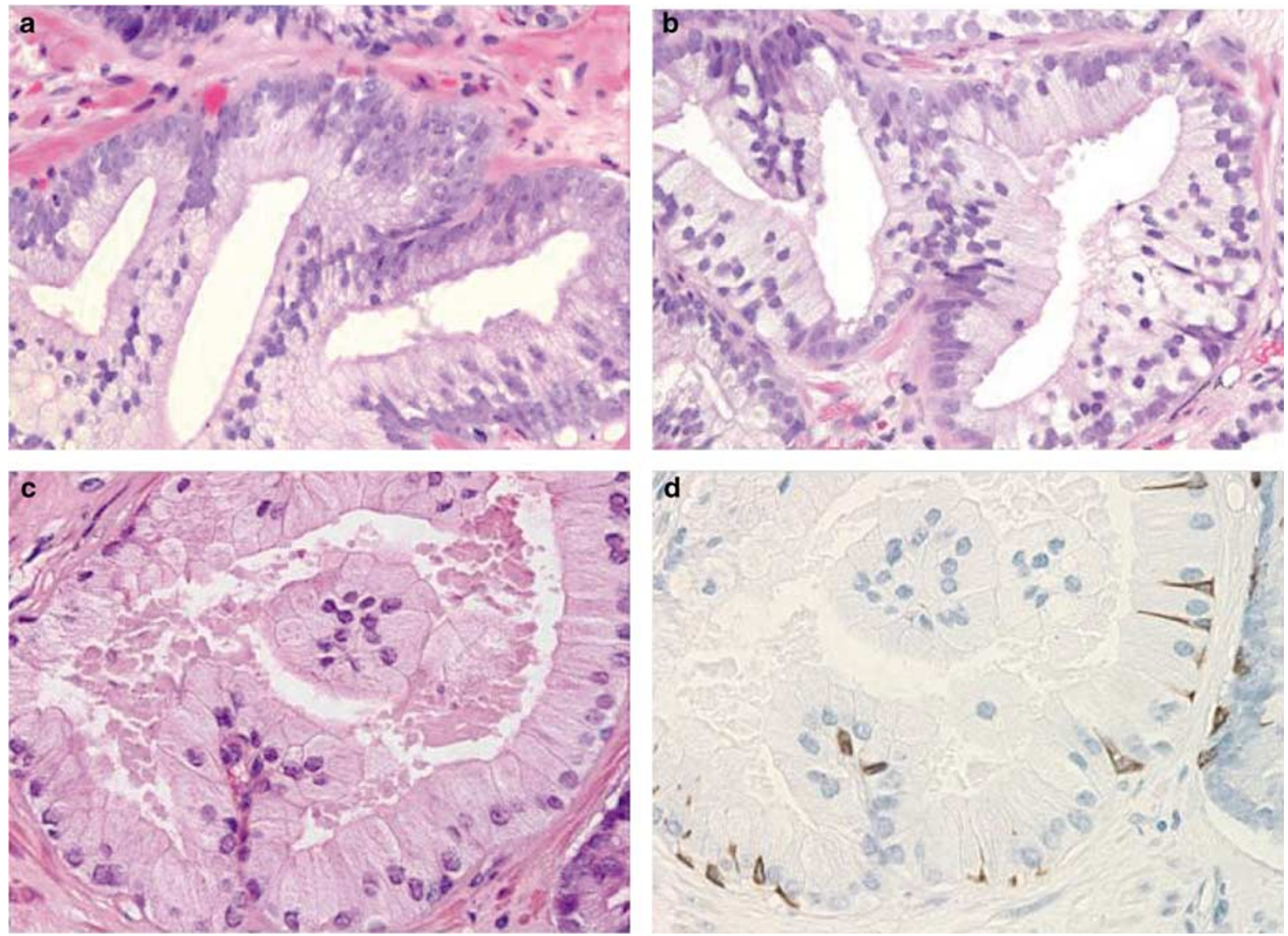

Figure 5 High-grade PIN with foamy cytoplasm (a-c). (d) Immunostain for 34ß12 reveals basal cell layer disruption in high-grade PIN.
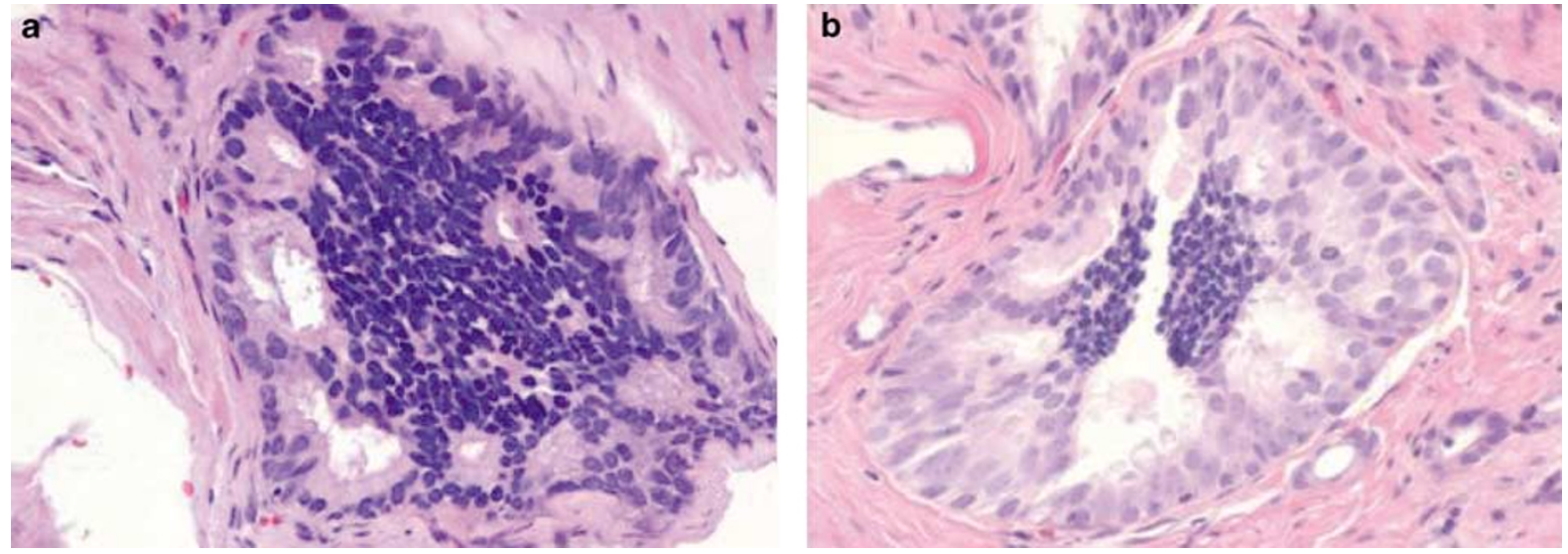

Figure 6 High-grade PIN with intraluminal small cells.

Cancer cells consistently fail to react with this antibody, although admixed benign acini may be misinterpreted as cancerous staining. Thus, immunohistochemical stains stains for antikeratin $34 \beta$ E12 may show the presence or absence of basal cells in a small focus of atypical glands, helping to establish a benign or malignant diagnosis respectively. We believe that this antibody can be employed successfully if one judiciously interprets the results in combination with the light microscopic findings; relying solely on the absence of immunoreactivity (absence of basal cell staining) to render the diagnosis of cancer is without precedent in diagnostic immunohistochemistry and is discouraged.$^{82}$ Nonetheless, recent reports have noted that the rate of equivocal cases can be reduced considerably, ${ }^{83}$ by $68 \%,{ }^{75}$ or from 5.1 to $1.0 \%{ }^{84}$ by addition of this immunohistochemical marker. Evaluation of 


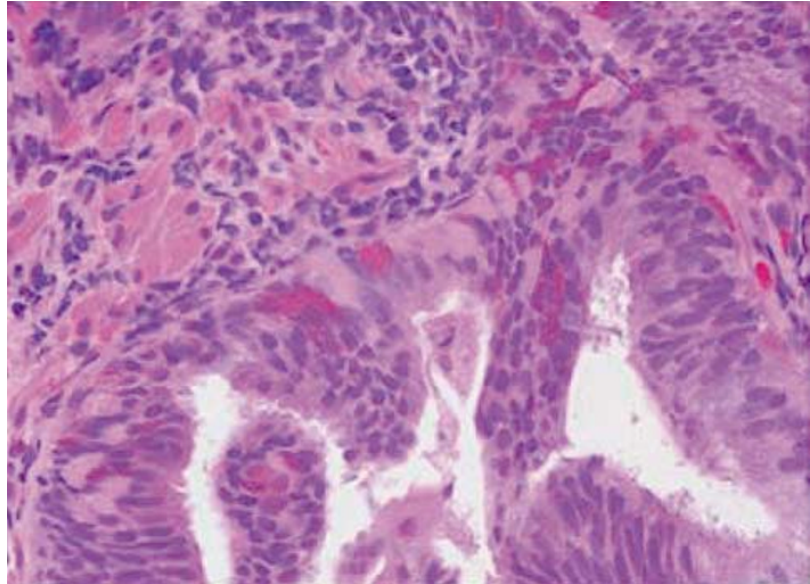

Figure 7 High-grade PIN with neuroendocrine cells (Paneth celllike change).

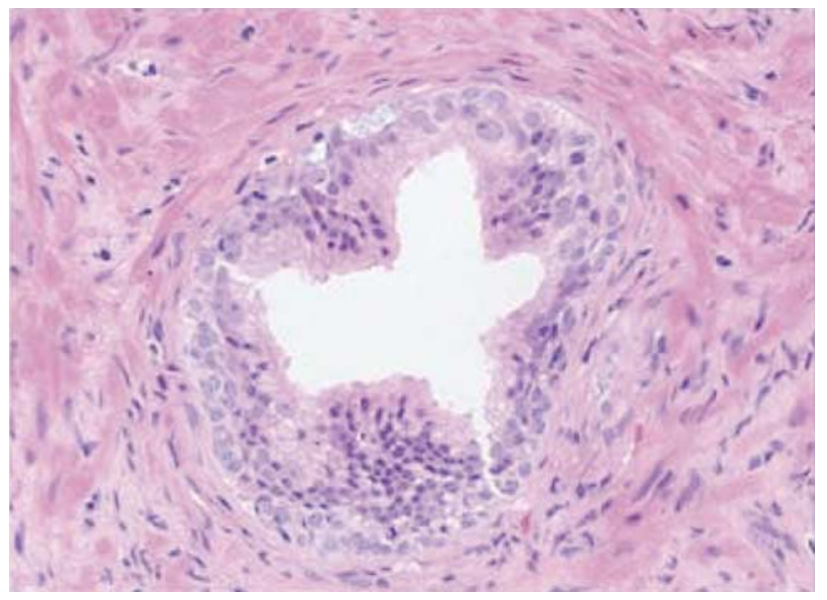

Figure 8 High-grade PIN with basal cell hyperplasia.

prostate biopsies following therapy such as radiation therapy may be one of the most useful roles for antikeratin 34 $\beta$-E12 (see below) ${ }^{85}$

In addition to PIN and cancer, basal cell layer disruption or loss also occurs in inflamed acini, atypical adenomatous hyperplasia, and postatrophic hyperplasia, and may be misinterpreted as cancer if one relies exclusively on the immunohistochemical profile of a suspicious focus. Furthermore, basal cells of Cowper's glands may not express keratin $34 \beta$-E12, ${ }^{86}$ although this has been disputed. ${ }^{87}$ Rare $(0.2 \%)$ cases of adenocarcinoma have been reported that express keratin $34 \beta$-E12, including foci of metastatic high-grade adenocarcinoma; these cases did not appear phenotypically to be basal cell/ adenoid cystic carcinoma. ${ }^{88}$

Basal cell hyperplasia is a histologic mimic of cancer, and use of antikeratin $34 \beta$-E12 is recommended in any equivocal cases that include this lesion in the differential considerations. ${ }^{89-91}$

CK5 and CK14 mRNA and protein are expressed in the basal cells of benign acini and PIN, and CK14
mRNA is present in low levels in the luminal cells of the most of some foci of PIN; thus, if PIN is derived from basal cells, as currently believed, CK14 translation is depressed and a low level of CK14 mRNA may persist. ${ }^{92}$ CK8 mRNA and protein were constitutively expressed in all epithelia of normal and abnormal prostate tissues. CK19 mRNA and protein were expressed in both basal and luminal cells of benign acini. CK16 mRNA was expressed in a similar pattern as CK19, but CK16 protein was not detected. ${ }^{92}$

We routinely generate unstained intervening sections of all prostate biopsies for possible immunohistochemical staining, recognizing that small foci of concern are often lost when the tissue block is recut; one study reported loss of the suspicious focus in 31 of 52 cases. $^{93}$

Other markers of basal cells include proliferation markers, differentiation markers, and genetic markers. The preferential localization of many of these markers in basal cells but not in secretory cells suggests that they play a role in growth regulation. P63 is a recently introduced nuclear marker that may be useful for separating PIN and cancer from benign mimic; however, experience with this is limited to date, and caution is urged owing to concerns with false-positive and false-negative staining. Basal cells display immunoreactivity at least focally for keratins $5,10,11,13,14,16$, and 19; of these, only keratin 19 is also found in secretory cells. ${ }^{94-97}$ Keratins found exclusively in the secretory cells include 7,8 , and 18. Basal cells usually do not display immunoreactivity for prostate-specific antigen (PSA), prostatic acid phosphatase (PAP), and S-100 protein, and only rare single cells stain with chromogranin and neuron-specific enolase. Conversely, the normal secretory luminal cells invariably stain with PSA and PAP. Prostatic basal cells do not usually display myoepithelial differentiation, ${ }^{96,98}$ in contrast with basal cells in the breast, salivary glands, pancreas, and other sites.

A new molecular marker, racemase (alpha-methylacyl-CoA racemase, P504S) was introduced for separating benign and neoplastic acini. This marker has proven useful for evaluation of ASAP (atypical small acinar proliferation suspicious for but diagnostic of cancer) and separation of cancer from hormonally treated benign acini. Its advantage over antikeratin $34 \beta$-E12 is its positive granular cytoplasmic staining in cancer cells, with little or no staining in benign acini. The gene for alpha-methylacyl-CoA racemase (AMACR) is greatly overexpressed in prostate cancer cells. AMACR is a well-characterized enzyme that catalyzes the conversion of several (2R)-methyl-branched-chain fatty acyl-CoAs to their (S)-stereoisomers. Analysis of mRNA levels of AMACR revealed an average upregulation of ninefold in prostate cancer. Other reports have substantiated the differential expression of this enzyme protein in benign and cancerous prostate tissues by immunohistochemistry. 


\section{Genetic and Molecular Changes}

High-grade PIN and prostate cancer share similar genetic alterations. ${ }^{1,99-102}$ For example, the frequent 8p12-21 allelic loss commonly found in prostate cancer was also found in microdissected PIN. ${ }^{99}$ Other examples of genetic changes found in carcinoma that already exist in PIN include loss of heterozygosity (LOH) at $8 \mathrm{p} 22,12 \mathrm{pter}-\mathrm{p} 12$, 10q11.2, ${ }^{21,99}$ and gain of chromosomes $7,8,10$, and $12 .{ }^{103}$ Alterations in oncogene bcl2 expression and RER + phenotype are similar for PIN and prostate cancer. ${ }^{104,105}$ In summary, these clinical and molecular studies taken together provide strong evidence that high-grade PIN is the main precursor of prostate cancer. The presence of high-grade PIN alerts both the clinician and the patient that progression to clinically significant prostate cancer is likely.

PIN is associated with progressive abnormalities of phenotype and genotype, which are intermediate between normal prostatic epithelium and cancer, indicating impairment of cell differentiation and regulatory control with advancing stages of prostatic carcinogenesis. ${ }^{106}$ There is progressive loss of some markers of secretory differentiation, including prostate-specific antigen, prostatic acid phosphatase, secretory proteins, ${ }^{94}$ cytoskeletal proteins,${ }^{94}$ glycoproteins such as blood group antigens, neuroendocrine cells, p-cadherin, ${ }^{107}$ fibroblast growth factor- $2,{ }^{108}$ inhibin, ${ }^{109}$ prostate-specific transglutaminase, ${ }^{110}$ androgen receptor expression, ${ }^{111}$ insulin-like growth factor binding protein-3, ${ }^{112}$ and telomerase. ${ }^{113}$ A member of the CIP/KIP family of cyclin-dependent kinase inhibitory proteins, p27KIP1, also showed significant reduction in expression in PIN, cancer, and metastatic cancer when compared with benign prostatic epithelium. ${ }^{114}$ Other markers show progressive increase, including including human glandular kallikrein 2 (hK2), ${ }^{115}$ c-erbB-2 (Her-2/neu) and c-erbB3 oncoproteins, ${ }^{108,116}$ c-met proto-oncogene, ${ }^{41}$ bcl-2 oncoprotein, ${ }^{117,118}$ mutator (RER(+)) phenotype, ${ }^{104}$ epidermal growth factor and epidermal growth factor receptor, ${ }^{108,119}$ type IV Collagenase, Lewis Y antigen, TGF-alpha, apoptotic bodies, ${ }^{71,73,104}$ mitotic figures, ${ }^{71}$ PCNA expression, Ki-67 expression, MIB-1 expression, ${ }^{111}$ tenascin-C, ${ }^{120}$ aneuploidy and genetic abnormalities, ${ }^{62,111,121-127}$ microvessel density, Ep-Cam transmembrane glycoprotein, ${ }^{128}$ Insulin-like growth factor binding protein IGFBP-rP1, and p53 mutations, ${ }^{129}$ although one group found no p53 expression immunohistochemically in PIN. ${ }^{130}$ Prostate-specific membrane antigen, an abundant transmembrane glycoprotein, shows increased expression in PIN and cancer when compared with benign epithelium, ${ }^{131,132}$ and this expression was unaffected by short-term androgen deprivation therapy. ${ }^{132}$ Estrogen receptor alpha is present in up to $28 \%$ of cases of PIN and $43 \%$ of cancers, but estrogen receptor beta is absent; ${ }^{133}$ prolactin receptor expression is increased in PIN. ${ }^{134}$
A model of prostatic carcinogenesis has been proposed based on the morphologic continuum of PIN and the multistep theory of carcinogenesis. ${ }^{1}$

\section{Microvessel density is increased In PIN}

PIN is virtually always accompanied by a proliferation of small capillaries in the stroma, despite separation from the underlying vasculature by a basal cell layer and basement membrane. It is likely that PIN initially coopts adjacent vessels, similar to other tumors, and that these vessels soon regress, only to be followed by vigorous angiogenesis at the cancer's edge. A critical balance exists between the proangiogenic vascular endothelial growth factor and the angiogenic antagonist angiopoietin-2.

Microvessel density is higher in high-grade PIN than in adjacent benign prostatic tissue, and the capillaries are shorter, more widely spaced, have more open lumina and curvaceous external contours, and are lined by a greater number of endothelial cells. The degree of microvessel density in PIN is intermediate between benign epithelium and cancer, lending support to the concept of PIN as the precursor of prostate cancer. Inhibition of angiogenesis may be an effective method of chemoprevention, particularly for men at high risk such as those who have high-grade PIN. It should be well tolerated in most adults because angiogenesis under typical conditions is needed only for reproduction and wound healing. ${ }^{65}$

\section{Animal Models of PIN and Prostate Cancer}

Several different animal models of prostate cancer have demonstrated that high-grade PIN is in the direct causal pathway to prostate cancer. ${ }^{135}$ The transgenic mouse model of prostate cancer (TRAMP) has been shown to mimic human prostate cancer. ${ }^{136,137}$ In the TRAMP model, the Probasin promoter-SV40 large $\mathrm{T}$ antigen (PB-Tag) transgene is expressed specifically in the epithelial cells of the murine prostate under the control of the probasin promoter. The probasin promoter is androgendependent. As a result, this model has several advantages over currently existing models: (1) mice develop progressive forms of prostatic epithelial hyperplasia and high-grade PIN as early as 10 weeks and invasive prostate adenocarcinoma around 18 weeks of age; ${ }^{136}(2)$ the pattern of metastatic spread of prostate cancer mimics that of human prostate cancer with common sites of metastases being lymph node, lung, kidney, adrenal gland and bone; (3) the development as well as the progression of prostate cancer can be followed within a relatively short period of 10-30 weeks; (4) spontaneous prostate tumors arise with $100 \%$ frequency; and (5) animals may be screened for the presence of the prostate cancer transgene prior to the onset of clinical prostate cancer. Another animal model is the transgenic mouse model that contains a probasin 
promoter that controls the ECO:R1 gene. This gene product has been implicated in the induction of genomic instability. ${ }^{138}$ Prostates from these animals were followed prospectively from 4 to 24 months of age and showed the progressive presence of mild to severe hyperplasia, low-grade PIN, high-grade PIN, and then well-differentiated adenocarcinoma of the prostate. ${ }^{138}$ Stanbrough et al ${ }^{139}$ demonstrated that transgenic mice that have prostatic overexpression of AR protein develop focal areas of high-grade PIN.

The mechanism of prostate carcinogenesis appears to involve estrogenic signaling. Wang et al ${ }^{140}$ treated wild-type mice with testosterone propionate and estradiol for 4 months. These mice developed prostatic hyperplasia, high-grade PIN, and invasive prostate cancer. When $\alpha$-ERKO mice, mice that have the ER $\alpha$ genetically knocked out, are treated the same way, they develop prostatic hyperplasia, but not high-grade PIN or invasive prostate cancer. ${ }^{140}$ Similarly, a prospective, placebo-controlled study of TRAMP mice treated with an antiestrogen, Acapodene (toremifene) was performed to pharmacologically antagonize ER $\alpha$. These acapodene-treated TRAMP mice had a reduction in high-grade PIN, significant decrease in prostate cancer incidence, and an increase in animal survival. Thus, estrogenic signally through ER $\alpha$ may play a key role; ${ }^{30}$ prostate carcinogenesis and that high-grade PIN was observed to be in the direct causal pathway to prostate cancer.

The dog is the only nonhuman species in which spontaneous prostate cancer occurs, and, like humans, the rate of canine prostate cancer increases with aging. ${ }^{141-145}$ High-grade PIN has been also observed in the prostates of these animals. ${ }^{142-145}$ Canine high-grade PIN shows cytological features identical to the human counterpart, including cell crowding, loss of polarity, and nuclear and nucleolar enlargement. Like prostatic adenocarcinoma, high-grade PIN also increases with aging. ${ }^{142}$ Highgrade PIN appears to represent an early event in prostate carcinogenesis that occurs with high frequency within the prostates of pet dogs sharing the same environment as humans. In this model, highgrade PIN was determined to be an intermediate step between benign epithelium and invasive carcinoma. Thus, like the transgenic mouse models, the canine model supports high-grade PIN as part of a continuum in the progression of prostate cancer.

\section{Clinical significance of PIN}

\section{PIN does not Elevate PSA}

Biopsy remains the definitive method for detecting PIN and early invasive cancer, but noninvasive methods, including serum tests, are being evaluated. Serum PSA concentration may be elevated in patients with PIN, ${ }^{146}$ although these results have been refuted. ${ }^{147,148}$ There is a poor correlation of PIN and PSA density according to studies of radical prostatectomy specimens and preoperative serum. ${ }^{148}$ Mean PSA increased from 8.4 to $11.6 \mathrm{ng} / \mathrm{ml}$ in patients with PIN who developed cancer within two years; those with PIN who did not develop cancer during this interval had an increase in PSA from 4.8 to $5.9 \mathrm{ng} / \mathrm{ml}$ or decrease from 5.1 to $4.6 \mathrm{ng}$ / $\mathrm{ml}$; however, these findings have not been confirmed.

The ratio of free to total PSA is the same for patients with high-grade PIN and cancer, unlike low-grade PIN and hyperplasia, although this has also been refuted. Many patients in these studies were later found to have cancer, so the elevation in serum PSA concentration and its derivatives may have resulted from the undetected cancer.

\section{Transrectal Ultrasound cannot Detect PIN}

By transrectal ultrasound, PIN may be hypoechoic like carcinoma, although these findings have not been confirmed. ${ }^{32}$ Today, most urologists and radiologists do not believe that PIN is detectable by transrectal ultrasound because PIN is a microscopic finding which is below the detection threshold for this form of imaging.

\section{Men with PIN Develop Prostate Cancer}

The predictive value of high-grade PIN was evaluated in a retrospective case-control study of 100 patients with sextant needle biopsies with high grade PIN and 112 biopsies without PIN matched for clinical stage, patient age, and serum PSA. ${ }^{149}$ Adenocarcinoma was identified in $36 \%$ of subsequent biopsies from cases with PIN, compared with $13 \%$ in the control group. The likelihood of finding cancer increased as the time interval from first biopsy increased $(32 \%$ incidence of cancer within 1 year, compared with $38 \%$ incidence in follow-up biopsies obtained after more than 1 year). Highgrade PIN, patient age, and serum PSA concentration were jointly highly significant predictors of cancer, with PIN providing the highest risk ratio (14.9). Other series have also found a high predictive value of PIN for cancer, although recent reports based on obtaining a greater number of cores shows a lower predictive value (Table 4). ${ }^{51,54-56,150-158}$ These data underscore the strong association of PIN and adenocarcinoma and indicate that vigorous diagnostic follow up is needed.

High-grade PIN in transurethral resection specimens is also an important predictive factor for prostate cancer. ${ }^{159,55}$ Among 14 patients with PIN and BPH followed for up to 7 years (mean, 5.9 years), three $(21.4 \%)$ developed prostatic cancer. ${ }^{159}$ Mean serum PSA concentration was higher than in those who did not develop cancer (8.1 vs $4.6 \mathrm{ng} / \mathrm{ml}$, respectively). All subsequent cancers apparently arose in the peripheral zone and were detected by needle biopsy. Thus, all tissue should be submitted 
Table 4 Cancer detection in patients with high-grade PIN

\begin{tabular}{|c|c|c|c|c|c|}
\hline Reference & Pt. population & $\begin{array}{l}\text { No. of } \\
\text { men }\end{array}$ & $\begin{array}{l}\% \text { patients with } \\
\text { cancer on } \\
\text { repeat biopsy }\end{array}$ & Control group? & Comment \\
\hline Brawer et $a l^{56}$ & Urology practice & 10 & 100 & No & Small study; no control group \\
\hline Ellis and Brawer ${ }^{150}$ & Urology practice & 5 & 100 & No & Small study; no control group \\
\hline Aboseif et al ${ }^{181}$ & Urology practice & 24 & 79.1 & No & Small study; no control group \\
\hline Weinstein and Epstein ${ }^{151}$ & Urology practice & 19 & 53 & No & Small study; no control group \\
\hline Keetch et al ${ }^{152}$ & PSA screening & 37 & 51 & $\begin{array}{l}\text { Yes; patients benign } \\
\text { biopsies }\end{array}$ & $\begin{array}{l}\text { Number of foci of PIN and linear extent } \\
\text { were not predictive of cancer }\end{array}$ \\
\hline Davidson et al ${ }^{149}$ & Two urology practices & 100 & 35 & $\begin{array}{l}\text { Yes; matched patients } \\
\text { with benign biopsy }\end{array}$ & $\begin{array}{l}\text { Pt. age older than } 65 \text { yearr and serum } \\
\text { PSA }>4 \mathrm{ng} / \mathrm{ml} \text { increased risk of later } \\
\text { cancer }\end{array}$ \\
\hline Markham $^{153}$ & Urology practice & 32 & 41 & No & $\begin{array}{l}\text { Diagnosis of PIN based on fine-needle } \\
\text { aspiration }\end{array}$ \\
\hline Raviv et $a l^{182,154}$ & Urology practice & 48 & 47.9 & $\begin{array}{l}\text { Yes; patients without } \\
\text { cancer on repeat biopsy }\end{array}$ & $\begin{array}{l}\text { DRE and PSA increased risk of later } \\
\text { cancer; PSA density not helpful }\end{array}$ \\
\hline Langer et $a l^{51}$ & Urology practice & 53 & 27 & No & $\begin{array}{l}\text { No difference in pt. age, PSA, or interval } \\
\text { to repeat biopsy between those with and } \\
\text { without cancer }\end{array}$ \\
\hline Berner et al ${ }^{183}$ & Oncology practice & 37 & 38 & Patients with $\mathrm{BPH}$ & $\begin{array}{l}\text { No difference in DNA ploidy status } \\
\text { between those with subsequent cancer } \\
\text { and those without }\end{array}$ \\
\hline Shepherd et $a l^{157}$ & PSA screening & 66 & 58 & No & $\begin{array}{l}\text { Quadrant location of PIN and cancer } \\
\text { matched in only } 35 \% \text { of cases }\end{array}$ \\
\hline Perachino et $a l^{54}$ & Urology practice & 21 & 71.1 & Patients without PIN & \\
\hline Krishnamurthi et al ${ }^{184}$ & Urology practice & 74 & 31 & No & $\begin{array}{l}\text { No difference in detection rate for cancer } \\
\text { by age, abnormal DRE, TRUS, PIS } \\
\text { velocity, or length of follow-up }\end{array}$ \\
\hline Rovner et al ${ }^{185}$ & Urology practice & 19 & 31.6 & Patients without PIN & $\begin{array}{l}\text { Transurethral biopsy was of no } \\
\text { diagnostic value }\end{array}$ \\
\hline Park et al ${ }^{186}$ & Urology practice & 43 & 51 & No & $\begin{array}{l}\text { Men with atypia or high-grade PIN merit } \\
\text { close follow-up }\end{array}$ \\
\hline Park et $a l^{158}$ & Urology practice & 104 & 22 & No & $\begin{array}{l}\text { PSA velocity, and DRE and TRUS } \\
\text { findings at initial biopsy were } \\
\text { independent predictors of malignant } \\
\text { disease on repeat biopsy }\end{array}$ \\
\hline Kronz et $a l^{187}$ & Urology practice & 245 & 32 & No & $\begin{array}{l}\text { The only independent histologic } \\
\text { predictor of a cancer diagnosis was the } \\
\text { number of cores with high-grade PIN }\end{array}$ \\
\hline Igel et $a l^{188}$ & Urology practice & 88 & 43 & No & $\begin{array}{l}\text { Only independent variable predictive of } \\
\text { positive biopsy was prostate volume }\end{array}$ \\
\hline
\end{tabular}


by the pathologist for examination when high-grade PIN is found in TURP specimens. The high predictive value of PIN for the development of subsequent cancer warrants reporting the presence of PIN in TURP specimens, according to the Cancer Committee of the College of American Pathologists. Conversely, a recent report showed that PIN in the transition zone and central zone from Norwegian men is not predictive of subsequent cancer development. ${ }^{160}$

\section{Androgen Deprivation Therapy Eliminates PIN}

There is a marked decrease in the prevalence and extent of high-grade PIN in cases after androgen deprivation therapy when compared with untreated cases. ${ }^{161-163}$ This decrease is accompanied by epithelial hyperplasia, cytoplasmic clearing, and prominent glandular atrophy, with decreased ratio of glands to stroma. These findings indicate that the dysplastic prostatic epithelium is hormone dependent. In the normal prostatic epithelium, luminal secretory cells are more sensitive to the absence of androgen than basal cells, and these results indicate that the cells of high-grade PIN share this androgen sensitivity. The loss of some normal, hyperplastic, and dysplastic epithelial cells with androgen deprivation is probably due to acceleration of programmed single cell death. A recent report suggested that PIN is not substantially decreased after hormonal therapy, but those authors failed to use current criteria for PIN, so the results are not comparable. ${ }^{164}$

Neoadjuvant hormone deprivation with monthly leuprolide and flutamide $250 \mathrm{mg}$ p.o. t.i.d. for 3 months resulted in a $50 \%$ reduction in high-grade PIN. Longer therapy with 6 months of neoadjuvant androgen deprivation therapy prior to radical prostatectomy in the European Randomized Study of Screening for Prostate Cancer (ERSPC) study reduced high-grade PIN even more. ${ }^{23}$ Flutamide decreased the prevalence and extent of high-grade PIN and induced epithelial atrophy. ${ }^{165}$ There is also evidence that cessation of flutamide resulted in return of high-grade PIN. ${ }^{16,166}$

The results of 5-alpha-reductase (finasteride) treatment in high-grade PIN are controversial and the cumulative number of cases studied is probably too small to draw firm conclusions. Two reports found no apparent effect on the histologic appearance or extent of high-grade PIN, ${ }^{167,168}$ whereas a third study of three cases described atrophy and involution with decreased prevalence. ${ }^{169}$

\section{Radiation Therapy Eliminates PIN}

The prevalence and extent of PIN is decreased after radiation therapy. ${ }^{170-172}$ However, one study paradoxically noted a higher incidence $(70 \%)$ of PIN after radiation therapy than expected, ${ }^{171}$ but they failed to employ accepted diagnostic criteria for PIN, so their results are not comparable with others. A recent report from Memorial Sloan-Kettering found PIN in $8.8 \%$ of biopsies following a course of threedimensional external beamconformal radiation therapy. ${ }^{172}$

Following radiation therapy, PIN retains the features characteristic of untreated PIN, and is readily recognized in tissue specimens. The key pathologic features include nuclear crowding, nuclear overlapping and stratification, nuclear hyperchromasia, and prominent nucleoli. The basal cell layer is present, but often fragmented. The most common patterns of PIN are tufting and micropapillary, similar to those reported in untreated PIN.

The long-term efficacy of radiation treatment may depend on eradication of cancer as well as precancerous lesions that may otherwise lead to evolution of secondary metachronous invasive cancers. Identification of residual or recurrent cancer portends a worse prognosis. The questions remain whether recurrent cancer after irradiation is due to regrowth of incompletely eradicated tumor or progression from incompletely eradicated PIN. Further studies of salvage prostatectomy specimens and post-RT needle biopsies are justified in an attempt to establish the significance of high-grade PIN as a source of long-term treatment failure among these patients. If PIN is associated with treatment failure, adjuvant chemoprevention strategies that ablate this lesion may reduce the risk of late cancer recurrence.

\section{Should Men with High-grade PIN be Treated?}

The clinical importance of recognizing PIN is based on its strong association with prostatic carcinoma. PIN has a high predictive value as a marker for adenocarcinoma, so its identification in biopsy specimens warrants further search for concurrent invasive carcinoma. If all procedures fail to identify coexistent carcinoma, close surveillance and followup are indicated. As high-grade PIN progresses, the likelihood of basal cell layer disruption increases, very much like what is observed for carcinoma in situ (CIS) of the urinary bladder. CIS of the urinary bladder, like PIN, may become invasive and is treated aggressively. The standard of care for management of CIS of the bladder is intravesical instillation of chemotherapy or BCG, and, in some cases, radical cystectomy.

Follow-up biopsy is suggested at 3-6-month intervals for 2 years, and thereafter at 12-month intervals for life. ${ }^{149,173}$ Some urologists have performed 'saturation' biopsies, consisting of more than 12-15 biopsies in one session, often with brief general anesthesia in the operating theatre, in an effort to definitively exclude cancer. Most authors agree that the identification of PIN in the prostate should not influence or dictate therapeutic 
decisions. ${ }^{173}$ We are aware of 21 radical prostatectomies that were purposely (three cases) or inadvertently performed (18 cases) in patients whose biopsies contained only high-grade PIN; all but two of the cases contained adenocarcinoma in the surgical specimen (DG Bostwick, personal communication, 2003).

Currently, routine treatment is not available for patients who have high-grade PIN. Prophylactic radical prostatectomy or radiation is not an acceptable treatment for patients who have high-grade PIN only. ${ }^{174}$ The development and identification of acceptable agents to treat high-grade PIN would fill a therapeutic void. As noted above, androgen deprivation therapy and radiation therapy induce acinar atrophy and apoptosis that result in regression of high-grade PIN. ${ }^{70,161-163,169,174-176}$

Chronic therapy, however, would most likely be required to prevent new high-grade PIN lesions from invading and becoming clinical prostate cancer. Although more toxicity is likely to be tolerated for the treatment agents targeted to regress or inhibit high-grade PIN, as compared to treating healthy patients to reduce prostate cancer incidence, androgen deprivation therapy has too many adverse effects in men to be clinically useful. Newer agents with better safety and lower side effect profile are greatly needed since patients may be taking the agent at least until they attain 70 years of age. ${ }^{174}$ Acapodene, an antiestrogen is currently in a Phase IIb multicenter, randomized, prospective placebocontrolled human clinical trial to determine if it can treat high-grade PIN and reduce prostate cancer incidence; preliminary results are encouraging. ${ }^{30}$

PIN offers promise as an intermediate end point in studies of chemoprevention of prostatic carcinoma. Recognizing the slow growth rate of prostate cancer and the considerable amount of time needed in animal and human studies for adequate follow-up, the noninvasive precursor lesion PIN is a suitable intermediate histologic marker to indicate subsequent likelihood of cancer.

\section{PIN Predicts Cancer Recurrence}

PIN was not predictive of PSA (biochemical) failure at 32 months in patients undergoing radical prostatectomy and androgen deprivation therapy. ${ }^{161}$

\section{Differential diagnosis of PIN}

The histologic differential diagnosis of PIN includes lobular atrophy, postatrophic hyperplasia, atypical basal cell hyperplasia (Figure 9), cribriform hyperplasia (Figure 10), and metaplastic changes
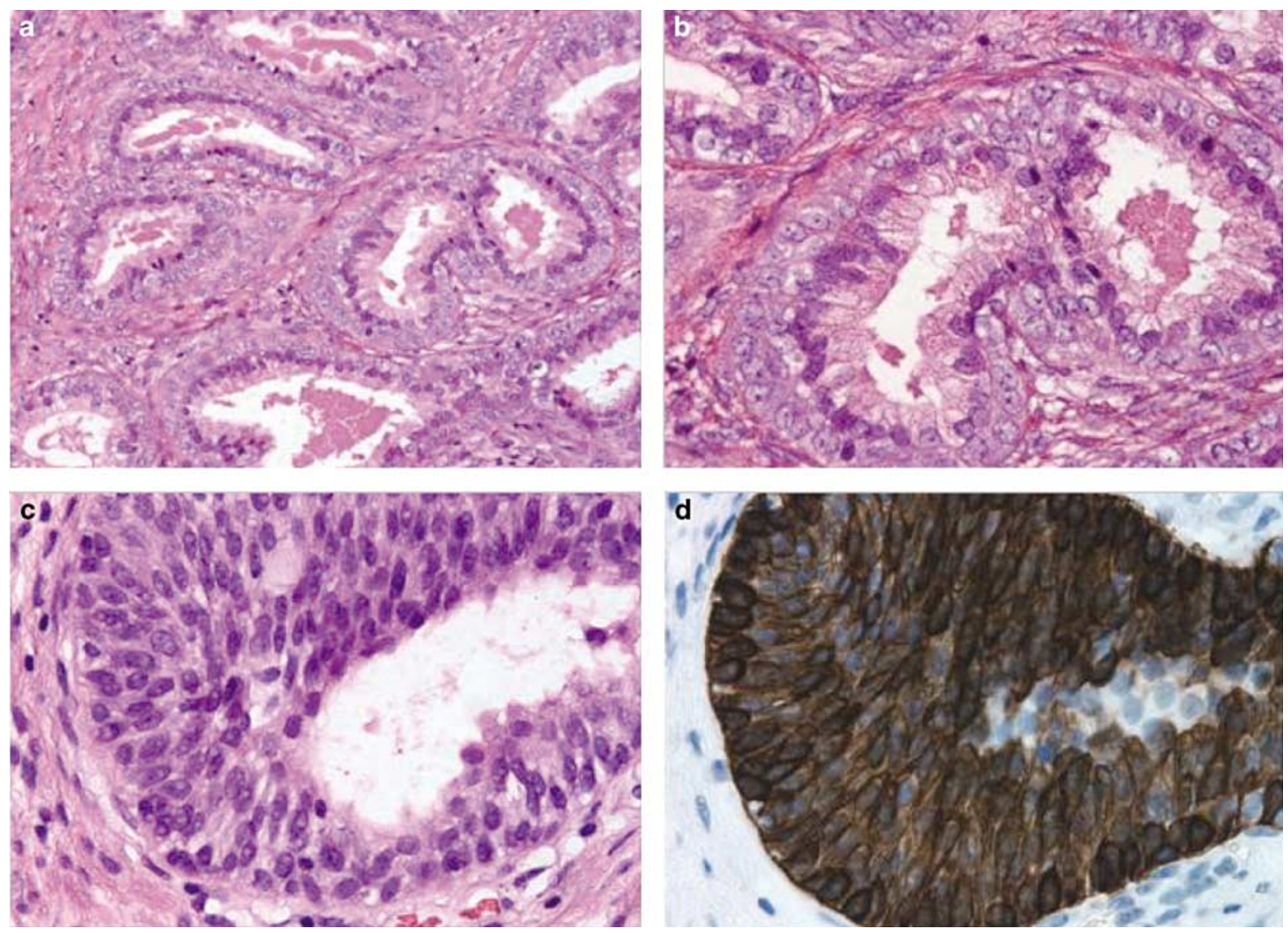

Figure 9 Atypical basal cell hyperplasia (a-c). (d) Immunostain for $34 \beta 12$ reveals strong basal cell staining. 
associated with radiation (Figure 11), infarction, and prostatitis. Many of these display architectural and cytologic atypia, including enlarged nucleoli,

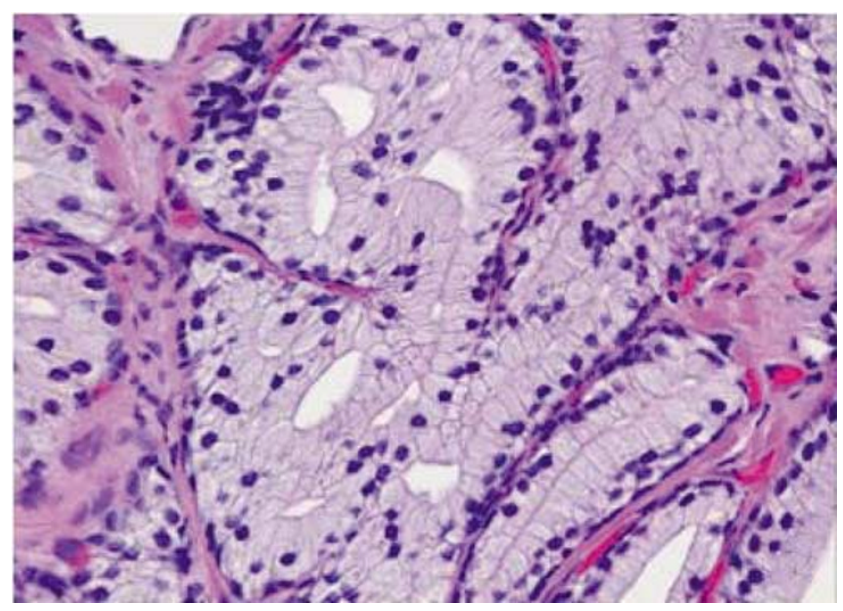

Figure 10 Clear cell cribriform hyperplasia showing bland cytology and basal cell layer around the gland.

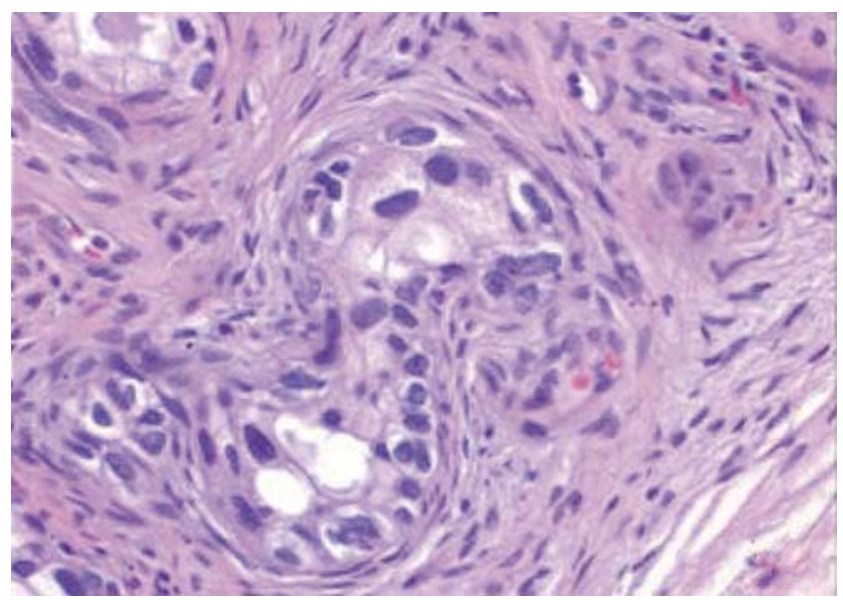

Figure 11 Benign prostatic tissue with radiation changes.

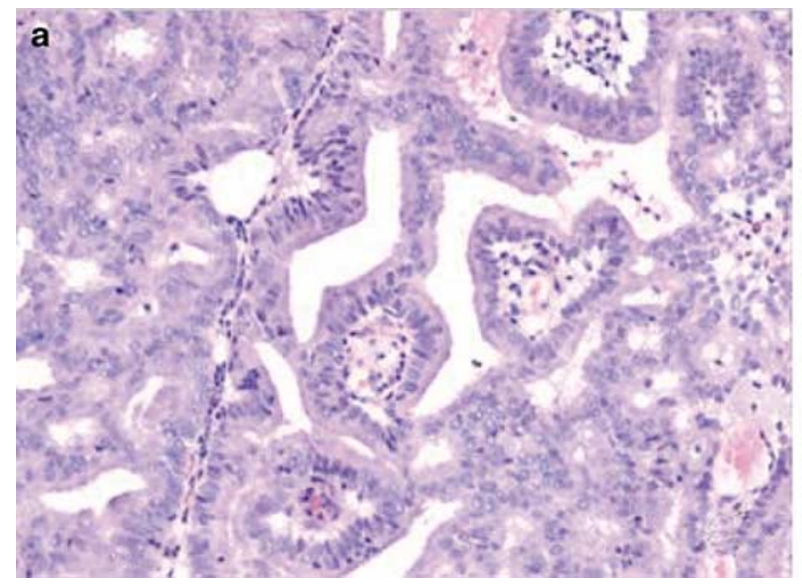

Figure 12 Ductal/papillary carcinoma. and small specimens, and cauterized or distorted specimen. Cribriform adenocarcinoma, ductal (endometrioid) carcinoma, and urothelial carcinoma involving prostatic ducts and acini may also be confused with PIN (Figure 12). Biopsies submitted with incomplete patient history should be interpreted with caution.

PIN may be overdiagnosed as adenocarcinoma. A retrospective review of transurethral resections from the Mayo Clinic files between 1960 and 1970 revealed that PIN was often diagnosed as adenocarcinoma. $^{177}$ Similarly, fine-needle aspiration of the prostate may yield cell clusters of PIN that are overdiagnosed as cancer; this issue is critically important to consider in evaluating studies from Sweden and other countries that have, perhaps erroneously, relied on fine-needle aspiration diagnoses for patients treated with watchful waiting (expectant management).

\section{Conclusion}

High-grade. PIN is the most likely precursor of prostatic adenocarcinoma, according to virtually all available evidence. PIN is associated with progressive abnormalities of phenotype and genotype, which are intermediate between normal prostatic epithelium and cancer, indicating impairment of cell differentiation and regulatory control with advancing stages of prostatic carcinogenesis. There is progressive loss of some markers of secretory differentiation, whereas other markers show progressive increase.

The clinical importance of recognizing PIN is based on its strong association with prostatic carcinoma. PIN has a high predictive value as a marker for adenocarcinoma, and its identification in biopsy specimens of the prostate warrants further search for concurrent invasive carcinoma. Studies to date have not determined whether PIN remains stable, regresses, or progresses, although the implication is that it can progress. 


\section{References}

1 Bostwick DG, Pacelli A, Lopez-Beltran A. Molecular biology of prostatic intraepithelial neoplasia. Prostate 1996;29:117-134.

2 Alcaraz A, Barranco MA, Corral JM, et al. High-grade prostate intraepithelial neoplasia shares cytogenetic alterations with invasive prostate cancer. Prostate 2001;47:29-35.

3 Sakr WA, Partin AW. Histological markers of risk and the role of high-grade prostatic intraepithelial neoplasia. Urology 2001;57:115-120.

4 Foster CS, Bostwick DG, Bonkhoff $\mathrm{H}$, et al. Cellular and molecular pathology of prostate cancer precursors. Scand J Urol Nephrol Suppl 2000;205:19-43.

5 Bostwick DG, Norlen BJ, Denis L. Prostatic intraepithelial neoplasia: the preinvasive stage of prostate cancer. Overview of the prostate committee report. Scand J Urol Nephrol Suppl 2000;205:1-2.

6 Bostwick DG, Montironi R, Sesterhenn IA. Diagnosis of prostatic intraepithelial neoplasia: Prostate Working Group/consensus report. Scand J Urol Nephrol Suppl 2000;205:3-10.

7 Zlotta AR, Schulman CC. Clinical evolution of prostatic intraepithelial neoplasia. Eur Urol 1999;35: 498-503.

8 Bostwick DG. Prostatic intraepithelial neoplasia is a risk factor for cancer. Semin Urol Oncol 1999;17: 187-198.

9 Algaba F. Evolution of isolated high-grade prostate intraepithelial neoplasia in a Mediterranean patient population. Eur Urol 1999;35:496-497.

10 Sakr WA. High-grade prostatic intraepithelial neoplasia: additional links to a potentially more aggressive prostate cancer? J Natl Cancer Inst 1998;90:486-487.

11 Bostwick DG, Shan A, Qian J, et al. Independent origin of multiple foci of prostatic intraepithelial neoplasia: comparison with matched foci of prostate carcinoma. Cancer 1998;83:1995-2002.

12 Montironi R, Mazzucchelli R, Pomante R. Preneoplastic lesions of the prostate. Adv Clin Pathol 1997;1:35-47.

13 Haggman MJ, Macoska JA, Wojno KJ, et al. The relationship between prostatic intraepithelial neoplasia and prostate cancer: critical issues. J Urol 1997; 158:12-22.

14 Montironi R, Bostwick DG, Bonkhoff H, et al. Origins of prostate cancer. Cancer 1996;78:362-365.

15 Shin HJ, Ro JY. Prostatic intraepithelial neoplasia: a potential precursor lesion of prostatic adenocarcinoma. Yonsei Med J 1995;36:215-231.

16 Prostatic Intraepithelial Neoplasia the Origins of Prostatic Carcinoma. Proceedings of the first international consultation meeting. Ancona, Italy, 11-12 September, 1994. Pathol Res Pract 1995;191:828-959.

17 Bostwick DG. Premalignant lesions of the prostate. Semin Diagn Pathol 1988;5:240-253.

18 McNeal JE, Yemoto CE. Spread of adenocarcinoma within prostatic ducts and acini. Morphologic and clinical correlations. Am J Surg Pathol 1996;20: 802-814.

19 McNeal JE, Bostwick DG. Intraductal dysplasia: a premalignant lesion of the prostate. Hum Pathol 1986;17:64-71.

20 Bostwick DG, Brawer MK. Prostatic intra-epithelial neoplasia and early invasion in prostate cancer. Cancer 1987;59:788-794.
21 Sakr WA, Grignon DJ, Haas GP, et al. Epidemiology of high grade prostatic intraepithelial neoplasia. Pathol Res Pract 1995;191:838-841.

22 Algaba F, Epstein JI, Aldape HC, et al. Assessment of prostate carcinoma in core needle biopsy-definition of minimal criteria for the diagnosis of cancer in biopsy material. Cancer 1996;78:376-381.

23 International consultation on prostatic intraepithelial neoplasia pathologic staging of prostatic carcinoma. Rochester, Minnesota, 3-4 November, 1995. Cancer 1996;78:320-381.

24 Project NPCD. Prostatic intraepithelial neoplasia: significance and correlation with prostate-specific antigen and transrectal ultrasound. Proceedings of a workshop of the National Prostate Cancer Detection Project. 13 March, 1989, Bethesda, MD. Urology 1989;34:2-69.

25 Epstein JI, Grignon DJ, Humphrey PA, et al. Interobserver reproducibility in the diagnosis of prostatic intraepithelial neoplasia. Am J Surg Pathol 1995;19: 873-886.

26 Allam CK, Bostwick DG, Hayes JA, et al. Interobserver variability in the diagnosis of high-grade prostatic intraepithelial neoplasia and adenocarcinoma. Mod Pathol 1996;9:742-751.

27 Algaba F, Epstein JI, Fabus G, et al. Working standards in prostatic intraepithelial neoplasia and atypical adenomatous hyperplasia. Pathol Res Pract 1995;191: 836-837.

28 Montironi R, Schulman CC. Precursors of prostatic cancer: progression, regression and chemoprevention. Eur Urol 1996;30:133-137.

29 Greenlee R, Hill-Harmon M, Murray T, et al. Cancer statistics, 2001. CA Cancer J Clin 2001;51:15-36.

30 Steiner MS, Raghow S, Neubauer BL. Selective estrogen receptor modulators for the chemoprevention of prostate cancer. Urology 2001;57:68-72.

31 Qian J, Wollan P, Bostwick DG. The extent and multicentricity of high-grade prostatic intraepithelial neoplasia in clinically localized prostatic adenocarcinoma. Hum Pathol 1997;28:143-148.

32 Lee F, Torp-Pedersen ST, Carroll JT, et al. Use of transrectal ultrasound and prostate-specific antigen in diagnosis of prostatic intraepithelial neoplasia. Urology 1989;34:4-8.

33 Sakr WA, Haas GP, Cassin BF, et al. The frequency of carcinoma and intraepithelial neoplasia of the prostate in young male patients. J Urol 1993;150: 379-385.

34 Sakr WA, Sarkar FH, Sreepathi P, et al. Measurement of cellular proliferation in human prostate by AgNOR, PCNA, and SPF. Prostate 1993;22:147-154.

35 Sakr WA, Billis A, Ekman P, et al. Epidemiology of high-grade prostatic intraepithelial neoplasia. Scand J Urol Nephrol Suppl 2000;205:11-18.

36 Sakr WA, Grignon DJ, Haas GP, et al. Age and racial distribution of prostatic intraepithelial neoplasia. Eur Urol 1996;30:138-144.

37 Sakr WA, Grignon DJ, Haas GP. Pathology of premalignant lesions and carcinoma of the prostate in African-American men. Semin Urol Oncol 1998;16: 214-220.

38 Fowler Jr JE, Bigler SA, Lynch C, et al. Prospective study of correlations between biopsy-detected high grade prostatic intraepithelial neoplasia, serum prostate specific antigen concentration, and race. Cancer 2001;91:1291-1296. 
39 Angwafo III FF, Zaher A, Befidi-Mengue R, et al. High-grade intra-epithelial neoplasia and prostate cancer in Dibombari, Cameroon. Prostate Cancer Prostatic Dis 2003;6:34-38.

40 Sakr WA. Prostatic intraepithelial neoplasia: a marker for high-risk groups and a potential target for chemoprevention. Eur Urol 1999;35:474-478.

41 Watanabe M, Fukutome K, Kato H, et al. Progressionlinked overexpression of c-Met in prostatic intraepithelial neoplasia and latent as well as clinical prostate cancers. Cancer Lett 1999;141:173-178.

42 Fujita M, Shin M, Yasunaga Y, et al. Incidence of prostatic intra-epithelial neoplasia in Osaka, Japan. Int J Cancer 1997;73:808-811.

43 Sakr WA, Grignon DJ, Crissman JD, et al. High grade prostatic intraepithelial neoplasia (HGPIN) and prostatic adenocarcinoma between the ages of 20-69: an autopsy study of 249 cases. In Vivo 1994;8: 439-443.

44 Helpap B, Bonkhoff H, Cockett A, et al. Relationship between atypical adenomatous hyperplasia (AAH), prostatic intraepithelial neoplasia (PIN) and prostatic adenocarcinoma. Pathologica 1997;89:288-300.

45 Bostwick DG, Aquilina JW. Prostatic intraepithelial neoplasia (PIN) and other prostatic lesions as risk factors and surrogate endpoints for cancer chemoprevention trials. J Cell Biochem Suppl 1996;25: 156-164.

46 Qian J, Bostwick DG. The extent and zonal location of prostatic intraepithelial neoplasia and atypical adenomatous hyperplasia: relationship with carcinoma in radical prostatectomy specimens. Pathol Res Pract 1995;191:860-867.

47 O’Dowd G J, Miller MC, Orozco R, et al. Analysis of repeated biopsy results within 1 year after a noncancer diagnosis. Urology 2000;55:553-559.

48 Richie JP, Kavoussi LR, Ho GT, et al. Prostate cancer screening: role of the digital rectal examination and prostate-specific antigen. Ann Surg Oncol 1994;1: 117-120.

49 Feneley MR, Busch C. Precursor lesions for prostate cancer. J R Soc Med 1997;90:533-539.

50 Hoedemaeker RF, Kranse R, Rietbergen JB, et al. Evaluation of prostate needle biopsies in a population-based screening study: the impact of borderline lesions. Cancer 1999;85:145-152.

51 Langer JE, Rovner ES, Coleman BG, et al. Strategy for repeat biopsy of patients with prostatic intraepithelial neoplasia detected by prostate needle biopsy. J Urol 1996;155:228-231.

52 Wills ML, Hamper UM, Partin AW, et al. Incidence of high-grade prostatic intraepithelial neoplasia in sextant needle biopsy specimens. Urology 1997;49: 367-373.

53 Skjorten FJ, Berner A, Harvei S, et al. Prostatic intraepithelial neoplasia in surgical resections: relationship to coexistent adenocarcinoma and atypical adenomatous hyperplasia of the prostate. Cancer 1997;79:1172-1179.

54 Perachino M, di Ciolo L, Barbetti V, et al. Results of rebiopsy for suspected prostate cancer in symptomatic men with elevated PSA levels. Eur Urol 1997; 32:155-159.

55 Gaudin PB, Sesterhenn IA, Wojno KJ, et al. Incidence and clinical significance of high-grade prostatic intraepithelial neoplasia in TURP specimens. Urology 1997;49:558-563.
56 Brawer MK, Bigler SA, Sohlberg OE, et al. Significance of prostatic intraepithelial neoplasia on prostate needle biopsy. Urology 1991;38:103-107.

57 Bostwick DG, Amin MB, Dundore P, et al. Architectural patterns of high-grade prostatic intraepithelial neoplasia. Hum Pathol 1993;24:298-310.

58 Reyes AO, Swanson PE, Carbone JM, et al. Unusual histologic types of high-grade prostatic intraepithelial neoplasia. Am J Surg Pathol 1997;21:1215-1222.

59 Bock BJ, Bostwick DG. Does prostatic ductal adenocarcinoma exist? Am J Surg Pathol 1999;23:781-785.

60 de la Torre M, Haggman M, Brandstedt S, et al. Prostatic intraepithelial neoplasia and invasive carcinoma in total prostatectomy specimens: distribution, volumes and DNA ploidy. Br J Urol 1993;72: 207-213.

61 Montironi R, Diamanti L, Pomante R, et al. Subtle changes in benign tissue adjacent to prostate neoplasia detected with a Bayesian belief network. J Pathol 1997;182:442-449.

62 Montironi R, Scarpelli M, Sisti S, et al. Quantitative analysis of prostatic intraepithelial neoplasia on tissue sections. Anal Quant Cytol Histol 1990;12: 366-372.

63 Qian J, Jenkins RB, Bostwick DG. Detection of chromosomal anomalies and c-myc gene amplification in the cribriform pattern of prostatic intraepithelial neoplasia and carcinoma by fluorescence in situ hybridization. Mod Pathol 1997;10:1113-1119.

64 Qian J, Jenkins RB, Bostwick DG. Genetic and chromosomal alterations in prostatic intraepithelial neoplasia and carcinoma detected by fluorescence in situ hybridization. Eur Urol 1999;35:479-483.

65 Montironi R, Diamanti L, Thompson D, et al. Analysis of the capillary architecture in the precursors of prostate cancer: recent findings and new concepts. Eur Urol 1996;30:191-200.

66 Montironi R, Mazzucchelli R, Algaba F, et al. Morphological identification of the patterns of prostatic intraepithelial neoplasia and their importance. J Clin Pathol 2000;53:655-665.

67 Montironi R, Scarpelli M, Galluzzi CM, et al. Aneuploidy and nuclear features of prostatic intraepithelial neoplasia (PIN). J Cell Biochem Suppl 1992;16H:47-53.

68 Qian J, Jenkins RB, Bostwick DG. Determination of gene and chromosome dosage in prostatic intraepithelial neoplasia and carcinoma. Anal Quant Cytol Histol 1998;20:373-380.

69 Qian J, Jenkins RB, Bostwick DG. Potential markers of aggressiveness in prostatic intraepithelial neoplasia detected by fluorescence in situ hybridization. Eur Urol 1996;30:177-184.

70 Montironi R, Pomante R, Diamanti L, et al. Apoptosis in prostatic adenocarcinoma following complete androgen ablation. Urol Int 1998;60(Suppl 1):25-29 discussion 30.

71 Montironi R, Magi-Galluzzi C, Fabris G. Apoptotic bodies in prostatic intraepithelial neoplasia and prostatic adenocarcinoma following total androgen ablation. Pathol Res Pract 1995;191:873-880.

72 Montironi R, Magi Galluzzi CM, Marina S, et al. Quantitative characterization of the frequency and location of cell proliferation and death in prostate pathology. J Cell Biochem Suppl 1994;19:238-245.

73 Montironi R, Magi Galluzzi C, Scarpelli M, et al. Occurrence of cell death (apoptosis) in prostatic 
intra-epithelial neoplasia. Virchows Arch A Pathol Anat Histopathol 1993;423:351-357.

74 Montironi R, Filho AL, Santinelli A, et al. Nuclear changes in the normal-looking columnar epithelium adjacent to and distant from prostatic intraepithelial neoplasia and prostate cancer. Morphometric analysis in whole-mount sections. Virchows Arch 2000;437: 625-634.

75 Novis DA, Zarbo RJ, Valenstein PA. Diagnostic uncertainty expressed in prostate needle biopsies. A College of American Pathologists Q-probes Study of 15,753 prostate needle biopsies in 332 institutions. Arch Pathol Lab Med 1999;123:687-692.

76 Wojno KJ, Epstein JI. The utility of basal cell-specific anti-cytokeratin antibody (34 beta E12) in the diagnosis of prostate cancer. A review of 228 cases. Am J Surg Pathol 1995;19:251-260.

77 Kahane H, Sharp JW, Shuman GB, et al. Utilization of high molecular weight cytokeratin on prostate needle biopsies in an independent laboratory. Urology 1995; 45:981-986.

78 Varma M, Linden MD, Amin MB. Effect of formalin fixation and epitope retrieval techniques on antibody 34betaE12 immunostaining of prostatic tissues [see comments]. Mod Pathol 1999;12:472-478.

79 Iczkowski KA, Cheng L, Crawford BG, et al. Steam heat with an EDTA buffer and protease digestion optimizes immunohistochemical expression of basal cell-specific antikeratin 34betaE12 to discriminate cancer in prostatic epithelium. Mod Pathol 1999; 12:1-4.

80 Goldstein NS, Underhill J, Roszka J, et al. Cytokeratin 34 beta E-12 immunoreactivity in benign prostatic acini. Quantitation, pattern assessment, and electron microscopic study. Am J Clin Pathol 1999;112:69-74.

81 Amin MB, Schultz DS, Zarbo RJ. Analysis of cribriform morphology in prostatic neoplasia using antibody to high-molecular-weight cytokeratins. Arch Pathol Lab Med 1994;118:260-264.

82 Ramnani DM, Bostwick DG. Basal cell-specific antikeratin antibody 34betaE12: optimizing its use in distinguishing benign prostate and cancer [editorial; comment]. Mod Pathol 1999;12:443-444.

83 Shin M, Fujita MQ, Yasunaga Y, et al. Utility of immunohistochemical detection of high molecular weight cytokeratin for differential diagnosis of proliferative conditions of the prostate. Int J Urol 1998;5: 237-242.

84 Freibauer C. Diagnosis of prostate carcinoma on biopsy specimens improved by basal-cell-specific anti-cytokeratin antibody (34 beta E12). Wien Klin Wochenschr 1998;110:608-611.

85 Brawer MK, Nagle RB, Pitts W, et al. Keratin immunoreactivity as an aid to the diagnosis of persistent adenocarcinoma in irradiated human prostates. Cancer 1989;63:454-460.

86 Saboorian MH, Huffman H, Ashfaq R, et al. Distinguishing Cowper's glands from neoplastic and pseudoneoplastic lesions of prostate: immunohistochemical and ultrastructural studies. Am J Surg Pathol 1997;21: 1069-1074.

87 Cina SJ, Silberman MA, Kahane H, et al. Diagnosis of Cowper's glands on prostate needle biopsy. Am J Surg Pathol 1997;21:550-555.

88 Yang XJ, Lecksell K, Gaudin P, et al. Rare expression of high-molecular-weight cytokeratin in adenocarcinoma of the prostate gland: a study of 100 cases of metastatic and locally advanced prostate cancer. Am J Surg Pathol 1999;23:147-152.

89 Bonkhoff H, Stein U, Remberger K. The proliferative function of basal cells in the normal and hyperplastic human prostate. Prostate 1994;24:114-118.

90 Epstein JI, Armas OA. Atypical basal cell hyperplasia of the prostate. Am J Surg Pathol 1992;16:1205-1214.

91 Devaraj LT, Bostwick DG. Atypical basal cell hyperplasia of the prostate. Immunophenotypic profile and proposed classification of basal cell proliferations. Am J Surg Pathol 1993;17:645-659.

92 Yang Y, Hao J, Liu X, et al. Differential expression of cytokeratin mRNA and protein in normal prostate, prostatic intraepithelial neoplasia, and invasive carcinoma. Am J Pathol 1997;150:693-704.

93 Green R, Epstein JI. Use of intervening unstained slides for immunohistochemical stains for high molecular weight cytokeratin on prostate needle biopsies. Am J Surg Pathol 1999;23:567-570.

94 Nagle RB, Brawer MK, Kittelson J, et al. Phenotypic relationships of prostatic intraepithelial neoplasia to invasive prostatic carcinoma. Am J Pathol 1991;138: 119-128.

95 O'Malley FP, Grignon DJ, Shum DT. Usefulness of immunoperoxidase staining with high-molecularweight cytokeratin in the differential diagnosis of small-acinar lesions of the prostate gland. Virchows Arch A Pathol Anat Histopathol 1990;417:191-196.

96 Srigley JR, Dardick I, Hartwick RW, et al. Basal epithelial cells of human prostate gland are not myoepithelial cells. A comparative immunohistochemical and ultrastructural study with the human salivary gland. Am J Pathol 1990;136:957-966.

97 Shah IA, Schlageter MO, Stinnett P, et al. Cytokeratin immunohistochemistry as a diagnostic tool for distinguishing malignant from benign epithelial lesions of the prostate [see comments]. Mod Pathol 1991;4: $220-224$.

98 Howat AJ, Mills PM, Lyons TJ, et al. Absence of S-100 protein in prostatic glands. Histopathology 1988;13: 468-470.

99 Emmert-Buck MR, Vocke CD, Pozzatti RO, et al. Allelic loss on chromosome 8p12-21 in microdissected prostatic intraepithelial neoplasia. Cancer Res 1995;55:2959-2962.

100 Kim NW, Hruszkewycz AM. Telomerase activity modulation in the prevention of prostate cancer. Urology 2001;57:148-153.

101 Willman JH, Holden JA. Immunohistochemical staining for DNA topoisomerase II-alpha in benign, premalignant, and malignant lesions of the prostate. Prostate 2000;42:280-286.

102 Ge K, Minhas F, Duhadaway J, et al. Loss of heterozygosity and tumor suppressor activity of Bin1 in prostate carcinoma. Int J Cancer 2000;86: 155-161.

103 Qian J, Bostwick DG, Takahashi S, et al. Chromosomal anomalies in prostatic intraepithelial neoplasia and carcinoma detected by fluorescence in situ hybridization. Cancer Res 1995;55:5408-5414.

104 Miet SM, Neyra M, Jaques R, et al. RER(+) phenotype in prostate intra-epithelial neoplasia associated with human prostate-carcinoma development. Int J Cancer 1999;82:635-639.

105 Baltaci S, Orhan D, Ozer G, et al. Bcl-2 protooncogene expression in low- and high-grade prostatic intraepithelial neoplasia. BJU Int 2000;85:155-159. 
106 Nasir A, Copeland J, Gillespie JW, et al. Preneoplastic lesions of the prostate-clinical, pathological and molecular biological aspects. In Vivo 2002;16: $557-566$.

107 Jarrard DF, Paul R, van Bokhoven A, et al. P-Cadherin is a basal cell-specific epithelial marker that is not expressed in prostate cancer. Clin Cancer Res 1997;3: 2121-2128.

108 Harper ME, Glynne-Jones E, Goddard L, et al. Expression of androgen receptor and growth factors in premalignant lesions of the prostate. J Pathol 1998; 186:169-177.

109 Zhang PJ, Driscoll DL, Lee HK, et al. Decreased immunoexpression of prostate inhibin peptide in prostatic carcinoma: a study with monoclonal antibody. Hum Pathol 1999;30:168-172.

110 Dubbink HJ, Hoedemaeker RF, van der Kwast TH, et al. Human prostate-specific transglutaminase: a new prostatic marker with a unique distribution pattern. Lab Invest 1999;79:141-150.

111 Tsuji M, Kanda K, Murakami Y, et al. Biologic markers in prostatic intraepithelial neoplasia: immunohistochemical and cytogenetic analyses. J Med Invest 1999;46:35-41.

112 Hampel OZ, Kattan MW, Yang G, et al. Quantitative immunohistochemical analysis of insulin-like growth factor binding protein-3 in human prostatic adenocarcinoma: a prognostic study. J Urol 1998;159: 2220-2225.

113 Koeneman KS, Pan CX, Jin JK, et al. Telomerase activity, telomere length, and DNA ploidy in prostatic intraepithelial neoplasia (PIN). J Urol 1998;160: 1533-1539.

114 Erdamar S, Yang G, Harper JW, et al. Levels of expression of p27KIP1 protein in human prostate and prostate cancer: an immunohistochemical analysis. Mod Pathol 1999;12:751-755.

115 Darson MF, Pacelli A, Roche P, et al. Human glandular kallikrein 2 (hK2) expression in prostatic intraepithelial neoplasia and adenocarcinoma: a novel prostate cancer marker. Urology 1997;49:857-862.

116 Myers RB, Srivastava S, Oelschlager DK, et al. Expression of p160erbB-3 and p185erbB-2 in prostatic intraepithelial neoplasia and prostatic adenocarcinoma. J Natl Cancer Inst 1994;86:1140-1145.

117 Colombel M, Symmans F, Gil S, et al. Detection of the apoptosis-suppressing oncoprotein bc1-2 in hormone-refractory human prostate cancers. Am J Pathol 1993;143:390-400.

118 Johnson MI, Robinson MC, Marsh C, et al. Expression of Bcl-2, Bax, and p53 in high-grade prostatic intraepithelial neoplasia and localized prostate cancer: relationship with apoptosis and proliferation. Prostate 1998;37:223-229.

119 Maygarden SJ, Strom S, Ware JL. Localization of epidermal growth factor receptor by immunohistochemical methods in human prostatic carcinoma, prostatic intraepithelial neoplasia, and benign hyperplasia. Arch Pathol Lab Med 1992;116:269-273.

120 Xue Y, Smedts F, Latijnhouwers MA, et al. Tenascin-C expression in prostatic intraepithelial neoplasia (PIN): a marker of progression? Anticancer Res 1998; 18:2679-2684.

121 Baretton GB, Vogt T, Blasenbreu S, et al. Comparison of DNA ploidy in prostatic intraepithelial neoplasia and invasive carcinoma of the prostate: an image cytometric study. Hum Pathol 1994;25:506-513.
122 Petein M, Michel P, van Velthoven R, et al. Morphonuclear relationship between prostatic intraepithelial neoplasia and cancers as assessed by digital cell image analysis. Am J Clin Pathol 1991;96:628-634.

123 Amin MB, Schultz DS, Zarbo RJ, et al. Computerized static DNA ploidy analysis of prostatic intraepithelial neoplasia. Arch Pathol Lab Med 1993;117: 794-798.

124 Weinberg DS, Weidner N. Concordance of DNA content between prostatic intraepithelial neoplasia and concomitant invasive carcinoma. Evidence that prostatic intraepithelial neoplasia is a precursor of invasive prostatic carcinoma. Arch Pathol Lab Med 1993;117:1132-1137.

125 Crissman JD, Sakr WA, Hussein ME, et al. DNA quantitation of intraepithelial neoplasia and invasive carcinoma of the prostate. Prostate 1993;22:155-162.

126 Saric T, Brkanac Z, Troyer DA, et al. Genetic pattern of prostate cancer progression. Int J Cancer 1999;81: 219-224.

127 Zitzelsberger H, Kulka U, Lehmann L, et al. Genetic heterogeneity in a prostatic carcinoma and associated prostatic intraepithelial neoplasia as demonstrated by combined use of laser-microdissection, degenerate oligonucleotide primed PCR and comparative genomic hybridization. Virchows Arch 1998;433:297-304.

128 Poczatek RB, Myers RB, Manne U, et al. Ep-Cam levels in prostatic adenocarcinoma and prostatic intraepithelial neoplasia. J Urol 1999;162:1462-1466.

129 Yasunaga Y, Shin M, Fujita MQ, et al. Different patterns of p53 mutations in prostatic intraepithelial neoplasia and concurrent carcinoma: analysis of microdissected specimens. Lab Invest 1998;78: 1275-1279.

130 Haussler O, Epstein JI, Amin MB, et al. Cell proliferation, apoptosis, oncogene, and tumor suppressor gene status in adenosis with comparison to benign prostatic hyperplasia, prostatic intraepithelial neoplasia, and cancer. Hum Pathol 1999;30: 1077-1086.

131 Bostwick DG, Pacelli A, Blute M, et al. Prostate specific membrane antigen expression in prostatic intraepithelial neoplasia and adenocarcinoma: a study of 184 cases. Cancer 1998;82:2256-2261.

132 Chang SS, Reuter VE, Heston WD, et al. Short term neoadjuvant androgen deprivation therapy does not affect prostate specific membrane antigen expression in prostate tissues. Cancer 2000;88:407-415.

133 Bonkhoff H, Fixemer T, Hunsicker I, et al. Estrogen receptor expression in prostate cancer and premalignant prostatic lesions. Am J Pathol 1999;155:641-647.

134 Leav I, Merk FB, Lee KF, et al. Prolactin receptor expression in the developing human prostate and in hyperplastic, dysplastic and neoplastic lesions. Am J Pathol 1999;154:863-870.

135 Bostwick DG, Ramnani D, Qian J. Prostatic intraepithelial neoplasia: animal models 2000. Prostate 2000;43:286-294.

136 Gingrich JR, Barrios RJ, Kattan MW, et al. Androgenindependent prostate cancer progression in the TRAMP model. Cancer Res 1997;57:4687-4691.

137 Greenberg NM, DeMayo F, Finegold MJ, et al. Prostate cancer in a transgenic mouse. Proc Natl Acad Sci USA 1995;92:3439-3443.

138 Voelkel-Johnson C, Voeks DJ, Greenberg NM, et al. Genomic instability-based transgenic models of prostate cancer. Carcinogenesis 2000;21:1623-1627. 
139 Stanbrough M, Leav I, Kwan PW, et al. Prostatic intraepithelial neoplasia in mice expressing an androgen receptor transgene in prostate epithelium. Proc Natl Acad Sci USA 2001;98:10823-10828.

140 Wang Y, Sudilovsky D, Zhang B, et al. A human prostatic epithelial model of hormonal carcinogenesis. Cancer Res 2001;61:6064-6072.

141 Aquilina JW, McKinney L, Pacelli A, et al. High grade prostatic intraepithelial neoplasia in military working dogs with and without prostate cancer. Prostate 1998;36:189-193.

142 Waters DJ. High-grade prostatic intraepithelial neoplasia in dogs. Eur Urol 1999;35:456-458.

143 Waters DJ, Bostwick DG. The canine prostate is a spontaneous model of intraepithelial neoplasia and prostate cancer progression. Anticancer Res 1997;17: 1467-1470.

144 Waters DJ, Bostwick DG. Prostatic intraepithelial neoplasia occurs spontaneously in the canine prostate. J Urol 1997;157:713-716.

145 Waters DJ, Hayden DW, Bell FW, et al. Prostatic intraepithelial neoplasia in dogs with spontaneous prostate cancer. Prostate 1997;30:92-97.

146 Kilic S, Kukul E, Danisman A, et al. Ratio of free to total prostate-specific antigen in patients with prostatic intraepithelial neoplasia. Eur Urol 1998;34: 176-180.

147 Ronnett BM, Carmichael MJ, Carter HB, et al. Does high grade prostatic intraepithelial neoplasia result in elevated serum prostate specific antigen levels? J Urol 1993;150:386-389.

148 Alexander EE, Qian J, Wollan PC, et al. Prostatic intraepithelial neoplasia does not appear to raise serum prostate-specific antigen concentration. Urology 1996;47:693-698.

149 Davidson D, Bostwick DG, Qian J, et al. Prostatic intraepithelial neoplasia is a risk factor for adenocarcinoma: predictive accuracy in needle biopsies. J Urol 1995;154:1295-1299.

150 Ellis WJ, Brawer MK. Repeat prostate needle biopsy: who needs it? J Urol 1995;153:1496-1498.

151 Weinstein MH, Epstein JI. Significance of high-grade prostatic intraepithelial neoplasia on needle biopsy. Hum Pathol 1993;24:624-629.

152 Keetch DW, Humphrey P, Stahl D, et al. Morphometric analysis and clinical followup of isolated prostatic intraepithelial neoplasia in needle biopsy of the prostate. J Urol 1995;154:347-351.

153 Markham CW. Prostatic intraepithelial neoplasia: detection and correlation with invasive cancer in fine-needle biopsy. Urology 1989;34:57-61.

154 Raviv G, Zlotta AR, Janssen T, et al. Do prostate specific antigen and prostate specific antigen density enhance the detection of prostate carcinoma after initial diagnosis of prostatic intraepithelial neoplasia without concurrent carcinoma? Cancer 1996;77: 2103-2108.

155 Raviv G, Janssen T, Zlotta AR, et al. Prostatic intraepithelial neoplasia: influence of clinical and pathological data on the detection of prostate cancer. J Urol 1996;156:1050-1054 discussion 1054-1055.

156 Berner A, Danielsen HE, Pettersen EO, et al. DNA distribution in the prostate. Normal gland, benign and premalignant lesions, and subsequent adenocarcinomas. Anal Quant Cytol Histol 1993;15:247-252.

157 Shepherd D, Keetch DW, Humphrey PA, et al. Repeat biopsy strategy in men with isolated prostatic intraepithelial neoplasia on prostate needle biopsy. J Urol 1996;156:460-462 discussion 462-463.

158 Park SJ, Miyake H, Hara I, et al. Predictors of prostate cancer on repeat transrectal ultrasoundguided systematic prostate biopsy. Int J Urol 2003;10:68-71.

159 Pacelli A, Bostwick DG. Clinical significance of highgrade prostatic intraepithelial neoplasia in transurethral resection specimens. Urology 1997;50: 355-359.

160 Harvei S, Skjorten FJ, Robsahm TE, et al. Is prostatic intraepithelial neoplasia in the transition/central zone a true precursor of cancer? A long-term retrospective study in Norway. $\mathrm{Br} \mathrm{J}$ Cancer 1998;78:46-49.

161 Balaji KC, Rabbani F, Tsai $\mathrm{H}$, et al. Effect of neoadjuvant hormonal therapy on prostatic intraepithelial neoplasia and its prognostic significance. J Urol 1999;162:753-757.

162 Ferguson J, Zincke H, Ellison E, et al. Decrease of prostatic intraepithelial neoplasia following androgen deprivation therapy in patients with stage T3 carcinoma treated by radical prostatectomy. Urology 1994;44:91-95.

163 Vailancourt L, Ttu B, Fradet Y, et al. Effect of neoadjuvant endocrine therapy (combined androgen blockade) on normal prostate and prostatic carcinoma. A randomized study. Am J Surg Pathol 1996;20: 86-93.

164 van der Kwast TH, Labrie F, Tetu B. Persistence of high-grade prostatic intra-epithelial neoplasia under combined androgen blockade therapy. Hum Pathol 1999;30:1503-1507.

165 Alers JC, Krijtenburg PJ, Vissers KJ, et al. Interphase cytogenetics of prostatic adenocarcinoma and precursor lesions: analysis of 25 radical prostatectomies and 17 adjacent prostatic intraepithelial neoplasias. Genes Chromosomes Cancer 1995;12:241-250.

166 Steiner MS. High-grade prostatic intraepithelial neoplasia and prostate cancer risk reduction. World J Urol 2003;21:15-20.

167 Civantos F, Watson RB, Pinto JE, et al. Finasteride effect on benign prostatic hyperplasia and prostate cancer. A comparative clinico-pathologic study of radical prostatectomies. J Urol Pathol 1997;6:1-8.

168 Yang XJ, Lecksell K, Short K, et al. Does long-term finasteride therapy affect the histologic features of benign prostatic tissue and prostate cancer on needle biopsy? PLESS Study Group. Proscar LongTerm Efficacy and Safety Study. Urology 1999;53: 696-700.

169 Montironi R, Pomante R, Diamanti L, et al. Evaluation of prostatic intraepithelial neoplasia after treatment with a 5-alpha-reductase inhibitor (finasteride). A methodologic approach. Anal Quant Cytol Histol 1996;18:461-470.

170 Bostwick DG, Neumann R, Qian J, et al. Reversibility of prostatic intraepithelial neoplasia: implications for chemoprevention. Eur Urol 1999;35:492-495.

171 Arakawa A, Song S, Scardino PT, et al. High grade prostatic intraepithelial neoplasia in prostates removed following irradiation failure in the treatment of prostatic adenocarcinoma. Pathol Res Pract 1995; 191:868-872.

172 Gaudin PB, Zelefsky MJ, Leibel SA, et al. Histopathologic effects of three-dimensional conformal external beam radiation therapy on benign and malig- 
nant prostate tissues. Am J Surg Pathol 1999;23: 1021-1031.

173 Bostwick DG. Prostatic intraepithelial neoplasia (PIN): current concepts. J Cell Biochem Suppl 1992; 16H:10-19.

174 Abbas F, Hochberg D, Civantos F, et al. Incidental prostatic adenocarcinoma in patients undergoing radical cystoprostatectomy for bladder cancer. Eur Urol 1996;30:322-326.

175 Bostwick DG, Qian J. Effect of androgen deprivation therapy on prostatic intraepithelial neoplasia. Urology 2001;58:91-93.

176 Montironi R, Magi-Galluzzi C, Muzzonigro G, et al. Effects of combination endocrine treatment on normal prostate, prostatic intraepithelial neoplasia, and prostatic adenocarcinoma. J Clin Pathol 1994;47: 906-913.

177 Bostwick DG, Chang L. Overdiagnosis of prostatic adenocarcinoma. Semin Urol Oncol 1999;17:199-205.

178 Mettlin C, Lee F, Drago J, et al. The American Cancer Society National Prostate Cancer Detection Project. Findings on the detection of early prostate cancer in 2425 men. Cancer 1991;67:2949-2958.

179 Fleshner NE, O’Sullivan M, Fair WR. Prevalence and predictors of a positive repeat transrectal ultrasound guided needle biopsy of the prostate. J Urol 1997; 158:505-508 discussion 508-509.

180 Bostwick DG, Qian J, Frankel K. The incidence of high grade prostatic intraepithelial neoplasia in needle biopsies. J Urol 1995;154:1791-1794.
181 Aboseif S, Shinohara K, Weidner N, et al. The significance of prostatic intra-epithelial neoplasia. Br J Urol 1995;76:355-359.

182 Raviv G, Janssen T, Zlotta AR, et al. [High-grade intraepithelial prostatic neoplasms: diagnosis and association with prostate cancer]. Acta Urol Belg 1996;64:11-15.

183 Berner A, Skjorten FJ, Fossa SD. Follow-up of prostatic intraepithelial neoplasia. Eur Urol 1996;30:256-260.

184 Kirschenbaum A, Klausner AP, Lee R, et al. Expression of cyclooxygenase-1 and cyclooxygenase- 2 in the human prostate. Urology 2000;56:671-676.

185 Rovner ES, Schanne FJ, Malkowicz SB, et al. Transurethral biopsy of the prostate for persistently elevated or increasing prostate specific antigen following multiple negative transrectal biopsies. J Urol 1997;158:138-141 discussion 141-142.

186 Park S, Shinohara K, Grossfeld GD, et al. Prostate cancer detection in men with prior high grade prostatic intraepithelial neoplasia or atypical prostate biopsy. J Urol 2001;165:1409-1414.

187 Kronz JD, Allan CH, Shaikh AA, et al. Predicting cancer following a diagnosis of high-grade prostatic intraepithelial neoplasia on needle biopsy: data on men with more than one follow-up biopsy. Am J Surg Pathol 2001;25:1079-1085.

188 Igel TC, Knight MK, Young PR, et al. Systematic transperineal ultrasound guided template biopsy of the prostate in patients at high risk. J Urol 2001; 165:1575-1579. 